\title{
Antidumping and Strategic Industrial Policy: Tit-for-Tat Trade Remedies and the China-X-Ray Equipment Dispute
}

\author{
MICHAEL O. MOORE* \\ George Washington University \\ MARK WU* \\ Harvard Law School
}

\begin{abstract}
This article examines the relationship between antidumping duties and strategic industrial policy. We argue that the dynamic between the two instruments is more complex and elaborate than that offered by the conventional account. We use the recent China-X-Ray Equipment dispute as a case study to show that linkage between the two instruments may not be the consequence of a government-led policy but instead a result of firm-driven responses to an industrial policy. This in turn may lead to antidumping tit-for-tat behavior between WTO members. We also analyze how WTO litigation serves as a means to alter the payoff and discuss the implications and unresolved questions that remain following the China-X-Ray Equipment ruling by the WTO.
\end{abstract}

\section{Introduction}

China-Definitive Anti-Dumping Duties on X-Ray Security Inspection Equipment from the European Union ('China-X-Ray Equipment') ${ }^{1}$ appears, at first glance, to be a run-of-the-mill antidumping dispute between two World Trade Organization (WTO) members. The legal issues are relatively pedestrian and involve procedural inadequacies of the Chinese trade remedy system. As with many WTO antidumping disputes, the party that imposed antidumping duties - in this case, China - was found to have violated certain WTO rules in the process. China then reformed its policies in line with the Panel Report. If one studied simply the facts and holding as set forth in the Panel Report itself, the case's significance might appear to lie in the WTO's clarification of the ways through which it can compel changes to domestic administrative procedures. The case does reaffirm the WTO's role as one of the few international fora with sufficient pull to entice governments to 'undo' rulings by

\footnotetext{
*Email: mom@email.gwu.edu.

** Email: mwu@law.harvard.edu.

1 Panel Report, China-Definitive Anti-Dumping Duties on X-Ray Security Inspection Equipment from the European Union, WT/DS425/R, 26 February 2013, adopted 24 April 2013.
} 
domestic administrative agencies - even if made by an agency in a powerful authoritarian state without a robust rule-of-law. ${ }^{2}$

But scratch beneath the surface and one will discover that China-X-Ray Equipment is about much more. The dispute provides an unusually vivid example of the deployment of antidumping measures by an incumbent oligopolistic firm seeking strategic advantage vis-à-vis a new foreign competitor supported by active government intervention. The relationship between industrial policy and strategic corporate use of antidumping has received relatively little attention in the literature. ${ }^{3}$ Most scholars, instead, have focused on the related issue of subsidies as an instrument of industrial policy and their legality under WTO rules. ${ }^{4}$ The long saga of WTO litigation over subsidies to Airbus and Boeing is a prominent example. But as global production patterns shift - in particular, with the rise of China-antidumping measures can play a critical role in affecting the playing field as latecomers attempt to crack into established markets.

We use the China-X-Ray Equipment dispute to highlight these strategic interactions. We illustrate how antidumping measures can be employed by both an incumbent and a newcomer to gain a relative advantage over the other. The established European Union (EU) incumbent, threatened by China's use of industrial policy to break into the EU market, strikes first with antidumping duties against the upstart; in response, the new Chinese competitor uses antidumping to gain advantage over the EU incumbent in the Chinese market. After highlighting the potential for tit-for-tat retaliation to emerge, we discuss how WTO dispute settlement functions as an additional litigation forum whose ruling can alter the firms' relative payoffs. Antidumping measures can therefore play an important role in advancing (or countering) a government's industrial policy and/or improving the competitive positions of firms in an oligopolistic industry.

In analyzing the relationship between antidumping and strategic industrial policy, we hope to make several contributions to the existing literature. First, we seek to expand the scholarly discussion of the array of trade policy instruments deployed in support of industrial policy and corporate strategic decisions. To date, the academic literature has concentrated primarily on the instruments of sub-

2 The WTO Dispute Settlement Body does not formally have any power to review domestic administrative rulings. However, it can review the legality of such rulings with a WTO member's WTO treaty commitments. If it finds the domestic administrative rulings to be inconsistent and the WTO member does not alter its ruling to conform to WTO rules, then the complainant in the WTO dispute is entitled to seek compensation or enact countermeasures pursuant to the WTO Dispute Settlement Understanding.

3 The academic literature has focused on the role of tariffs in strategic trade and industrial policies but not antidumping duties as the particular tool. To the extent that scholars have focused on the use of antidumping measures in conjunction with industrial policy, the attention has been primarily on strategic use of antidumping by governments and not firms. See, for example, Hindley and Messerlin (1996).

4 See, for example, Bora et al. (2000); Feris (2011); Pangetsu (2002). 
sidies and local content requirements when examining this nexus. ${ }^{5}$ This article expands this discussion to include antidumping measures.

We expand upon the conventional account of how antidumping duties interact with industrial policy. The standard approach suggests that antidumping duties function in much the same way as other trade-related instruments of industrial policy. The policy initiative is government-led, and the policy measure is embedded within the government's overall industrial policy strategy. While we acknowledge that this is possible in many scenarios, we seek to draw attention to an alternative mechanism. This is one in which the government may not start out intending to use antidumping measures as a prong of its industrial policy. Instead, antidumping duties emerge over the course of time as its trading partners react to its domestic firm's increasing competitiveness (on account of its industrial policy support). Moreover, the instrument itself may emerge because of firm-led initiatives calling for the government to take action to counter and/or support industrial policy. Furthermore, the dynamic can be further exacerbated on account of retaliatory pressures. In short, we argue that the conventional account is incomplete and ought to take into account the possible of alternative - and more complicated mechanisms through which antidumping measures come into play with an industrial policy.

Secondly, we aim to expand scholarly understanding of how antidumping measures and industrial policy are linked in a specific jurisdiction-China. This subject has received little attention in either the legal or economic scholarship, whether in English or Chinese. ${ }^{6}$ Yet, China is undoubtedly a major global player on both fronts. As part of its successful economic development drive, the Chinese government has actively championed the use of industrial policy. This, in turn, has contributed to industrial policy's resurgent popularity among scholars (Rodrik 2010). China has also emerged as a major user of antidumping measures over the past 15 years. Understanding the linkages between these two is important for enhancing our knowledge of what motivates economic and trade policy in the world's second largest economy.

This nexus has been relative obscure until recently. Only since 2010 have China's trading partners started to challenge its antidumping measures before the WTO. Even so, such challenges have been limited. The China-X-Ray Equipment ruling represents only the second time that the WTO Dispute Settlement Body (DSB) has opined on the legality of China's antidumping practices. ${ }^{7}$ While scholars

5 See, for example, Eaton and Grossman (1986); Feris (2011); Greenway and Milner (1993); Hufbauer et al. (2013).

6 One paper which has examined this topic is Zeng and Abrami (2011). They note the importance of local interests and structural factors.

7 The first was the China-GOES case. See Panel Report, China-Countervailing and Anti-Dumping Duties on Grain Oriented Flat-Rolled Electrical Steel from the United States, WT/DS414/R, 15 June 2012, adopted 16 November 2012, and Appellate Body Report, China-Countervailing and 
such as Wu (2012) and Zeng (2012) have recently shed greater light on features of China's antidumping system, including its tendency to engage in tit-for-tat retaliation, a number of questions remain unanswered. For example, how is it that the impetus for a retaliatory action emerges? To what extent do industrial policy considerations factor into Chinese antidumping decisions?

This article aims to expand our understanding of these important questions. We suggest that China's actions do not necessarily always fit the top-down, centrally driven pattern that is commonly assumed to be the case with Chinese industrial policy. Instead, it can be externally forced and firm-led, with the state playing a critical but reactive role. In the China-X-Ray Equipment dispute, we highlight how two firms (one European, the other Chinese) took the lead in pressing for antidumping measures in their respective home markets. ${ }^{8}$ These moves, in turn, raised operating costs for both firms in their export markets. While the results and interactions are consistent with formal models of strategic trade policy, the policy itself was not government-initiated. We therefore suggest that greater attention ought to be devoted to the complexities of interfirm dynamics and how they impact the government-firm relationship in China.

Thirdly, this article seeks to highlight how WTO litigation can impact the payoff that results from employing antidumping duties in support of a strategic industrial policy. We demonstrate how this is done through litigation squabbles over highly technical details of WTO antidumping law. In particular, we draw attention to the issue of product market definition, both as it relates to antidumping determinations generally and to the execution of a specific measure tied to an industrial policy. We explain how Chinese authorities sought to manipulate the product definition to help its domestic producer, and we commend the WTO's ruling taken in response. We posit that the recent WTO Panel ruling, however, will not be the definitive word on this question. The article highlights issues that remain unresolved in light of the recent ruling and why we expect the issue to reemerge in future litigation.

The article is organized as follows: Section 2 sets forth our simplified and stylized view of the dynamic at work between strategic industrial policy and antidumping measures. Section 3 then applies this to the particular facts in the China-X-Ray Equipment dispute, noting how the application of strategic industrial policy by China eventually culminates in tit-for-tat antidumping measures and a WTO dispute. Section 4 describes how WTO litigation factors into this dynamic, through a discussion of the Panel Report in China-X-Ray Equipment. Section 5 analyzes three specific legal and economic issues that arise from the China-XRay Equipment case. These concern: (1) the efficacy of deploying antidumping measures in the manner described in this article; (2) issues concerning product

Anti-Dumping Duties on Grain Oriented Flat-Rolled Electrical Steel from the United States, WT/DS414/ $\mathrm{AB} / \mathrm{R}, 18$ October 2012, adopted 16 November 2012.

8 As we will discuss, there are other firms producing this product and so this is not an example of pure duopoly interaction. 
market definition that remain unresolved following the Panel Report; and (3) how WTO litigation may be advancing rule-of-law in a particular context of Chinese administrative law. Concluding remarks appear in Section 6.

\section{The relationship between antidumping and industrial policy}

Industrial policy refers generally to a government's support of domestic firms in sectors deemed to be important to broader social welfare. One reason that a government might intervene is in the case of a domestic 'infant industry', i.e., one with high initial fixed costs that make it initially uncompetitive but with an eventually competitive cost structure. New domestic companies may face established foreign enterprises with lower costs and dominant market share. Industrial policy support may come in the form of direct subsidies, access to below-market rates for capital, or provision of cheap inputs to the newly established domestic firms. Economic theory suggests that such support could be welfare-improving in the event that there are important 'positive externalities', such as technological spillovers, that benefit the country as a whole and that are not part of the individual firm's own decision-making calculus. Alternatively, domestic financial markets may be inefficient so that potentially competitive enterprises do not receive the requisite capital to develop. The goal of industrial policy might be to offer temporary support that would allow domestic firms to expand output, spread the fixed costs over longer production runs, and become competitive at home and even abroad. 9

In the 1980s and 1990s, economists extensively explored this theoretical possibility of active government industrial policy that could lead to a new competitive domestic sector in international markets. This general focus of the literature is known by the moniker 'strategic trade policy'. A classic article particularly relevant to the current discussion can be found in Krugman (1984), who formalized the notion that government could protect a domestic firm in a sector with increasing economies of scale. The resulting protection would not only raise the costs of the foreign firm through decreased production but also could lower domestic costs through increased production. This in turn could lead to increased export opportunities for the now lower-cost domestic firm. Such an improved competitive position is not guaranteed but is possible.

There is decidedly mixed evidence about whether this type of protection for domestic industries is effective in practice. Westphal (1990) found that selective interventions by the South Korean government were critical in boosting the export competitiveness of several Korean industries. Rodrik (1995) also found that

9 However, note that not all government programs would be welfare improving; over-subsidization could lead, for example, to inefficient overproduction, thereby swamping the positive externalities. Tariffs can impose costs to consumers that may overwhelm the benefits to the protected industry. 
government intervention laid the groundwork for South Korea's and Taiwan's economic successes. Dick (1994), on the other hand, found little evidence that import protection allowed industries in the United States to expand their exports. Irwin (2000) found that tariffs played an important role in establishing the US tinplate industry in the $1890 \mathrm{~s}$ but at high costs to the rest of the US economy. More recently, Stiglitz and Lin have compiled two extensive volumes examining industrial policy successes and failures in various contexts (Stiglitz and Lin Yifu 2013; Stiglitz et al. 2013).

The same state can succeed in some instances and fail in others. Luzio and Greenstein (1995) documented Brazil's failure to foster a domestic computer industry using import protection. Goldstein (2002), on the other hand, demonstrated the important role played by the Brazilian state in transforming its regional aircraft manufacturer into a global force. Similarly, the European civilian airplane industry might never have gotten on its feet without government support. Neven and Seabright (1995) found that European industrial policies for Airbus had a demonstrably positive impact on European welfare, albeit at the expense of global welfare. Owen (2012) argued that European governments have consistently failed to replicate this industrial policy success in other high-tech industries, because they overestimated the degree of market failures and underestimated the risks and costs associated with government failure. Various scholars, including most recently Lin and Monga (2010), have tried to posit the conditions under which industrial policy can succeed, but much remains unknown.

A key aspect of an industrial policy is the provision of a benefit to the domestic firm. In the latecomer scenario associated with strategic trade theory and discussed earlier, this benefit can take on a variety of forms. Some focus on shifting the cost curve. Subsidies and cheaper domestic inputs, for example, lower the private cost of the domestic upstart. Increased tariffs, on the other hand, raise the cost of the foreign incumbent. So too does the imposition of formal or informal barriers to entry-some of which may succeed in keeping the foreign incumbent out of the market altogether. Other forms focus on influencing demand rather than supply conditions, including the provision of consumer subsidies or procurement policies. Regardless, each of these policy instruments is designed to alter market conditions in order to shift market share to the domestic firm(s).

If the government's chosen policy involves raising tariffs against foreign producers and the country is a WTO member, then the government will find that its actions are constrained as a result of treaty law. Article I of the General Agreement on Tariffs and Trade (GATT) requires that WTO member governments not impose tariffs beyond the bound rates to which they have committed in their tariff schedules. Consequently, a government seeking to raise a foreign firm's cost must turn to other policy instruments. This is how antidumping duties enter into the picture.

GATT Article II:2(b) provides that antidumping duties are an exception to the Article I obligations on tariffs. GATT Article VI and the Antidumping 
Agreement (ADA) negotiated in the Uruguay Round allow a WTO member to raise tariffs beyond the bound rate provided certain conditions are met. The decision over whether to impose an antidumping duty is made by domestic authorities, usually through a judicial process before an administrative agency. ${ }^{10}$ However, this decision is subject to review by national courts and subject to challenge through the WTO dispute settlement process.

Antidumping duties can be targeted against specific foreign firms for a very narrow product category. They therefore can play a strategic role in helping a domestic producer against a foreign competitor. This feature, along with the treaty constraints set forth in GATT Article I, make it a potentially appealing instrument to advance an industrial policy by raising a foreign competitor's costs inside the domestic market.

The relationship of antidumping duties and industrial policy has received relatively little attention in scholarship to date. Both Bora et al. (2000: 19) and Pangetsu (2000: 154) devote only a single paragraph to antidumping duties when discussing the trade-related industrial policy instruments in reports for the United Nations and the World Bank, respectively. One might think that the most extensive treatment of the subject would be found in a book titled Antidumping Industrial Policy by Hindley and Messerlin (1996). However, a closer examination of the book's content finds that it is focused primarily on examining the lack of economic justification for antidumping duties rather than the precise nature of the measure's relationship with industrial policy.

The limited discussion to date has posited that the relationship between antidumping duties and strategic industrial policy is relatively similar to that of other trade instruments designed to provide import protection. This conventional account suggests that governments use antidumping duties as a first-order industrial policy instrument in order to artificially create scale advantages for a domestic firm, just as it might with subsidies or non-tariff barriers. Both Bora et al. (2000: $19)$ and Pangetsu (2000: 154) suggest that this is most commonly done for declining industries, and many of the instances on which Hindley and Messerlin (1996) focus are of that type.

We suggest however that the conventional account is incomplete. To begin with, the import protection might be for a new upstart, rather than a declining industry. More importantly, however, we argue that the conventional account captures only one potential mechanism through which the two forces interact. We suggest that there are potentially other viable mechanisms through which antidumping duties come into play with a strategic industrial policy. Such mechanisms can be firmdriven rather than government-led. Importantly, antidumping petitions normally

10 In some countries, this can be before two different administrative agencies. For example, in the United States, the process requires separate hearings before the Department of Commerce and the International Trade Commission. 
are filed by firms; only rarely do governments self-initiate an investigation. An antidumping measure is not typically embedded as a first-order instrument in an industrial policy; instead, it emerges more organically as trading partners react to each other's policies. Below, we spell out these mechanisms in a stylized form.

Suppose that an established incumbent firm in Country A has a large market share both domestically and internationally. If this is a sector with economies of scale, the incumbent firm also has low average costs. Assume further that the government in Country B would like to establish domestic firms in this sector because of perceived externalities. Country B's government might therefore impose formal or informal barriers on the incumbent firm in order to allow the domestic firm to exploit its own potential scale economies. As Country B's new entrants' costs fall as a result of government intervention, it might move into direct competition in the incumbent's domestic market.

Note, however, that so far, antidumping duties have not necessarily entered into the equation. While they may have served as the means through which Country B insulated its domestic firms from the incumbent in its home market (in the manner posited by the conventional account), the chances are greater that Country B's government would have chosen to rely upon another policy instrument instead to drive its industrial policy (e.g., production subsidies or below-market interest rates). How then do antidumping duties emerge under this second scenario where they are not an element of Country B's initial industrial policy?

Consider the following question: What are the options available to the incumbent firm in Country A if it faces competition from a new, government-supported entrant from Country B? If Country B employed a subsidy to support the domestic upstart, then Country A's firm might seek for its government to impose countervailing duties against the new entrant. However, what if an alternative policy instrument were used instead such as government procurement preferences in a country not subject to treaty obligations as set forth in the WTO Government Procurement Agreement (GPA)? Or what if Country B were a 'non-market economy' that might present additional legal complications in terms of a subsidy determination? ${ }^{11}$ Country A's firm might instead seek the imposition of antidumping duties to counter Country B's new entrant.

The imposition of antidumping duties in this manner triggers the reverse of dynamics set forth in Krugman (1984): The home market of the embattled incumbent is closed to the new entrant. The imposition of antidumping duties could result in lower costs to the incumbent and higher costs to the entrant.

This therefore represents a second mechanism through which antidumping duties interface with strategic industrial policy. Instead of serving as the direct

11 See Prusa and Vermulst (2013) for a general discussion of the treatment of non-market economies in the GATT/WTO trade remedies context and a focused discussion as it applies to the issue of double remedies. 
means for implementing an industrial policy by a government seeking to protect its market to benefit a late entrant, antidumping duties may also serve as the means through which trade restrictions help an embattled incumbent protect its domestic market against imports from a new entrant that had benefited previously from strategic industrial policy.

Furthermore, the story need not end here. Faced with an effort to shut its exports out of the incumbent's market, the incentives for retaliation from Country B now increase. Academic research has long established that governments might impose their own antidumping duties in retaliation for antidumping duties on their own exporters. ${ }^{12}$ One reason to do so is to generate a deterrent effect for future action.

But how and where should Country B seek to retaliate? If a government is simply seeking to signal its displeasure or to affect its trading partner's political economy through creating additional general economic distress, then it might choose to retaliate against a powerful export sector or one that is politically well connected. For example, after the EU imposed antidumping duties against Chinese solar panels, China threatened to retaliate with antidumping duties against European wine.

However, when retaliation occurs via a different product, Country B's new entrant remains disadvantaged by Country A's antidumping measure. Country B's firm therefore might seek government support to reverse this disadvantage. It could petition for its government to retaliate by imposing antidumping duties against its competitor's product directly. This represents a classic tit-for-tat retaliation scenario. Governments are conveying the message, 'If you harm my exporter, then I'll hurt yours'. Antidumping duties serve as the vehicle for delivering the punch-counterpunch. ${ }^{13}$

The above discussion should make clear that the mechanisms through which antidumping measures interface with strategic industrial policy vary and could be more complicated than the traditional government-led model. Such interactions also can arise as a consequence of a firm's strategic corporate decisions.

\section{Case study: $x$-ray scanners and tit-for-tat antidumping measures}

We turn to the recent China-X-Ray Equipment dispute as a case study of how industrial policy intersects with antidumping measures in an actual competition between an established incumbent and an upstart backed by industrial policy.

12 See, for example, Prusa and Skeath (2002); Bown and Crowley (2007); Moore and Zanardi (2011). 13 Retaliation, however, is effective only if Country B's market is important to Country A's exporter. For firms on both sides, the gains from having antidumping duties imposed on one's competitor in one's home market may be offset by the losses incurred by having antidumping duties imposed on one's exports abroad. Only if the effect of the latter is sufficiently large does it create incentives for firms on both sides to push their governments to seek a settlement. 
Before elaborating on the details of this case study, it is worth noting that the relationship between an antidumping measure and an industrial policy is not always readily apparent to an outside observer. A scholar focused simply on the legal holding of the WTO case might very well have missed the industrial policy backdrop to the dispute. Unlike other trade-related industrial policy instruments (e.g., export subsidies), the instrument is not necessarily enmeshed within the government's industrial policy. Therefore, discussion of industrial policy may not surface at all during the course of the WTO legal proceedings. Moreover, even if one had assumed that the Chinese antidumping measures at issue were part of a broader industrial policy, one might have incorrectly presumed that they operated in accordance with the mechanism described in the conventional account - as part of a Chinese strategy to protect a domestic market to achieve a scale economy for its upstart to enhance its competitiveness overseas. Yet, as we will see, the actual dynamic can be much more complicated.

To uncover the connections between an antidumping measure and strategic industrial policy requires that one's analysis extends beyond the legal issues in the case itself. Indeed, it was only through a series of off-the-record conversations with lawyers and government officials that we grew to understand the complicated interconnections among the forces at work in the China-X-Ray Equipment dispute.

\subsection{Overview of the established incumbents in the global $x$-ray scanners market}

The products at the heart of the dispute are the $\mathrm{x}$-ray machines for scanning large cargo items such as railroad cars and trucks. These scanners use relatively sophisticated technology and are purchased primarily by governments for border security measures. Depending on the size and use of the machines, the technology employed differs. The machines for large objects use high-energy beams; similar scanners for hand baggage utilize lower-energy x-rays. This difference will prove to be important later for the case.

In the wake of the 11 September 2001 terrorist attacks, demand for x-ray scanners increased. Not surprisingly, as the market grew, international competition heightened. Until the mid-2000s, however, the global market for x-ray scanners was dominated primarily by a handful of producers in the developed world. In recent years, a Chinese producer has managed to gain share in this growing market, at least partly as a consequence of Chinese government industrial policy. Indeed, the product's technical sophistication, its high start-up costs, and the oligopolistic nature of the industry fit well into the scenario envisioned in many theoretical setups for strategic industrial policy.

The story here is of a battle between two rivals - a European incumbent and a Chinese upstart-for the global x-ray scanner market. Antidumping duties surface as part of the struggle between the two, with each appealing to its government to take action to keep the other out of its home market. 
The incumbent is Smiths Heimann GmbH ('Smiths'), the German branch of Smiths Detection PLC, an EU-based multinational company housed within the Smiths Group PLC, a European conglomerate. By the late 2000s, Smiths held a dominant position within the European market, accounting for approximately $80 \%$ of total EU production of the relevant x-ray scanners. ${ }^{14}$ How was Smiths able to achieve such a dominant hold over the European market? Part of the story may very well be the high quality of its products. But Smiths' own annual reports hint at another possible factor that may have played a role. As noted in several of its annual reports, the vast majority of Smiths' sales are to governments and government agencies around the world. Some European governments may very well have preferred to purchase from a European producer. The fact that Smiths resides within a pan-European conglomerate, coupled with its long-time presence in the sector, likely made Smiths an attractive recipient of European government procurement contracts for $\mathrm{x}$-ray scanners. ${ }^{15}$

Smiths is also a market leader worldwide, but its global share is much less dominant than in Europe. In 2008, Smiths led the world with a 29\% market share in scanners for the 'explosives, weapons, and contraband equipment' sector. ${ }^{16}$ The global market is much more fragmented for x-ray scanners for ports and borders (the relevant sector for this case). Smiths' traditional competitors in this sector are primarily US-based multinationals. ${ }^{17}$ Today, according to Smiths, they include Rapiscan, American Science and Engineering (ASE), and Leidos (formerly 'SAIC'). ${ }^{18}$ Smiths and this group of American companies dominated sales in the growing market for x-ray scanners until the mid-2000s.

\subsection{China's quest to build a latecomer entrant through strategic industrial policy}

The emergence of a Chinese producer in the past decade has resulted in a major disruption to the landscape of players competing for a share of the global market for $\mathrm{x}$ ray scanners. In many ways, this story is similar to the narrative that has played out for many other industrial products. However, in this instance, the disruption began with domestic sales rather than through an export-led strategy.

14 Council Implementing Regulation (EU) No. 510/2010 of 14 June 2010 Imposing a Definitive AntiDumping Duty and Collecting Definitively the Provisional Duty Imposed on Imports of Certain Cargo Scanning Systems Originating in the People's Republic of China, Official Journal, L150/1, 16 June 2010.

15 Smiths, however, did not operate in a fully protected home market. As we discuss later in this section, European governments also regularly awarded contracts to non-European competitors.

16 See Smiths Group PLC 2008 Annual Report which references a study by IMS Research.

17 Smiths Group PLC 2013 Annual Report.

18 See Rapiscan description in parent company OSI Systems, Inc'.s 2013 Annual Report; Leidos Inc. 2014 Annual Report; and ASE 2013 Annual Report. Note that Leidos is primarily focused on the US market while Rapiscan and ASE are both engaged in sales worldwide. 
Over the past two decades, China has invested vast sums to upgrade its infrastructure. These investments, in turn, have generated tremendous demand for x-ray scanners to safeguard Chinese ports, roads, airports, railway hubs, subways, etc.

In some sectors, China has willingly turned to foreign imports to meet its growing demand. In others, however, China has attempted to create a national champion. ${ }^{19}$ Because of the underlying importance of security to the regime, it would not be surprising for the Chinese government to view the x-ray scanners market as one in which they would prefer a domestic 'champion'. We are not aware of any available government document that explicitly sets forth such a strategy but several interesting facts point strongly to this possibility.

Segal (2010) notes that Beijing's strategy has been to rely on a mixture of topdown and bottom-up initiatives focused on developing capacity in 'fields that affect the lifeblood of the national economy and national security'. Certainly, security scanners for infrastructure would appear to qualify as such a field. Bottom-up initiatives have centered on university-industry collaboration and venture capital. That precisely has been the approach used to cultivate a domestic Chinese producer to challenge the established European and American players in the $\mathrm{x}$-ray scanners market.

The Chinese firm that has become a major global player is Nuctech Company Ltd. ('Nuctech'). It is, however, not just another Chinese company. Nuctech was created in 1997 at Tsinghua University, China's premier university for science and technology. ${ }^{20}$ Even after the firm was spun off, Tsinghua University remains active in it; it is the leading shareholder in Nuctech through its investment holding company, Tsinghua Holdings. As in many other start-ups, Nuctech's CEO during the course of its initial rapid growth was a dynamic young man named $\mathrm{Hu} H$ Haifeng. $\mathrm{Hu}$ is a Tsinghua alumnus, having received his executive MBA there. He also is the son of $\mathrm{Hu}$ Jintao, China's top leader from 2002 to 2012 and prior to that, its Vice President. In 2008, based on his success at Nuctech, Hu Haifeng was promoted to become the Communist Party secretary of Tsinghua Holdings.

Nuctech grew by executing a strategy modelled on the one employed by Smiths in Europe. It sought to become the dominant producer within its home market and then leverage this dominance to become a major player worldwide. This strategy proved effective at least in part because of the dominance of government procurement contracts in this market and because of Nuctech's close ties with the government.

19 For example, China's Five-Year Plans designate certain key strategic sectors. China has also advocated for greater indigenous innovation in certain sectors. See Ahrens (2010); Fu and Gong (2011).

20 Tsinghua University is sometimes referred to as the 'MIT of China'. Over the past two decades, several research initiatives initially based at Tsinghua have been spun off as private companies. Tsinghua's experience, in this regard, is similar to that of other top research universities worldwide. However, Tsinghua also features as part of the government's efforts to cultivate bottom-up indigenous capacity in key industrial sectors. 
Just as European governments may prefer to buy x-ray scanners from a European company, Nuctech counted on the fact that the Chinese government too would prefer to buy from a Chinese company, especially one run by the President's son. Furthermore, as China is not a party to the GPA, its government's actions in this sector are even less constrained compared to its European and American competitors (whose governments have signed on to the GPA). In the late 2000s, Nuctech accounted for approximately a $90 \%$ share of the domestic Chinese market (Erickson 2010). ${ }^{21}$

Like Smiths, Nuctech took advantage of its strong position in its home market to expand overseas. In 2001, Nuctech won a bid to install x-ray scanners at the ports of Sydney and Melbourne. By 2008, Nuctech had won contracts in over 60 countries, many in the developing world (Goodwin 2008). This included supplying $\mathrm{x}$-ray scanners for the port of Los Angeles, a contract that Nuctech won by outbidding Smiths and SAIC.

What accounts for Nuctech's success? Part of it may be due to Nuctech's ability to develop a lower-cost alternative to the x-ray scanners offered by incumbents. For several contracts, Nuctech outbid its competitors on the basis of price. But industrial policy also likely played a role. Government agencies account for the vast majority of China's purchases of x-ray equipment, and those agencies delivered business to Nuctech. Hints of an industrial policy agenda also can be found in a Tsinghua University press release trumpeting Nuctech's early success in Australia. It describes the deal as 'a successful step in the Chinese government's strategy to translate technological advantages into commercial uses'. ${ }^{22}$

Nuctech, however, has sought to distance itself from the Chinese government. In explaining why Nuctech was awarded a contract to supply scanners to detect liquid explosives to all 147 airports in China ahead of the 2008 Olympics, an official noted that Nuctech's products were deemed the most satisfactory. While acknowledging that Nuctech did have connections to the President's son, the official said that this 'had no effect on our decision', adding that ' $t]$ his has to do with people's lives, and you can't play games with safety'. ${ }^{23}$ Similarly, authorities for the port of Los Angeles, in the wake of their controversial decision to use government funds to buy Chinese products from President Hu's son's company, also explained that their decision was driven primarily by price. ${ }^{24}$

21 Note that it is likely that the figures on which Erickson (2010) relies are those from the years prior to the publication of his book. As we shall see, by 2010, Nuctech's share had started to decline as it ceded ground in the domestic market to Smiths.

22 See Li Jing, Tsinghua University News, 28 December 2001, http://news.tsinghua.edu.cn/publish/ newsen/6055/2011/20110222163200067683361/20110222163200067683361_.html.

23 'Nuctech to Install Liquid Bomb Detectors Ahead of China Olympics', Homeland Security News Wire, 18 December 2006.

24 Nuctech's bid was nearly $30 \%$ lower than its closest competitor (Smiths). See 'Port of LA Buys Security Scanners from Chinese Firm', Defense Industry Daily, 21 October 2008, https://www.defenseindustrydaily.com/cat/geographical-focus/asia/asia-china/page/6/. 
Nuctech's competitors, however, contend that ties between the company and the Chinese government remain strong. They allege that the Chinese government provides soft loans to allow Nuctech's customers to pay for the x-ray scanners and that government policies allow Nuctech to drive down price to win contracts (Aldrick et al., 2009). However, despite these allegations, no government to date has challenged China on this matter before the WTO. ${ }^{25}$

Nuctech's rise nicely illustrates two points: First, the story is consistent with theories of strategic trade policy. The Chinese government nurtured an 'infant industry' in a sector with increasing economies of scale through import protection. The government's industrial policy allowed Nuctech to increase production and lower its costs by keeping foreign products largely out of the growing Chinese market. This, in turn, boosted Nuctech's export competitiveness and allowed Nuctech to emerge as a lower-cost competitor to the established incumbents.

Second, antidumping duties do not feature as part of the Chinese government's initial industrial policy. Import protection is achieved through other trade-related policy instruments besides antidumping - namely, government procurement and indirect export subsidies. ${ }^{26}$ To the extent that the Chinese government played a role in nurturing Nuctech's success, it was not through the use of antidumping duties. The conventional account of how antidumping duties intersect with strategic industrial policy therefore is not what played out in this instance.

\subsection{EU Antidumping action to ward off Chinese entrant}

How then did antidumping duties enter into the picture? As suggested in section 2, an alternative mechanism is possible - one which is firm-led in reaction to an industrial policy. This is precisely what happened in this instance. By the 2000s, Nuctech had started to make impressive inroads worldwide, including against Smiths in its European home market. For example, in 2006, the port of Dublin awarded Nuctech a contract to supply x-ray scanners for its facilities. Nuctech's share of the x-ray scanner market in Europe more than doubled between 2004 and 2006. ${ }^{27}$ A critical component of Nuctech's successful strategy was its price,

25 Note that Nuctech has been subject to an anticorruption investigation in Namibia. However, this action involves actions of company officials and does not appear to be tied to the Chinese government. Nevertheless, the Chinese government has censored reports of this investigation. See Gordon Faircloth et al., 'Probe Involves Firm Linked to China Leader's Son', Wall Street Journal, 22 July 2009.

26 As noted earlier, we do not mean to single out China for engaging in this form of economic nationalism. Other governments will also consider nationality when making procurement decisions and make active use of their export-import banks. To the extent that China differs from other trading countries, it may be in the scale of its efforts, especially as China is not constrained by the WTO's Government Procurement Agreement, to which it is not a member.

27 Official Journal L510/9 at para. 79. Note that Nuctech's market share remained at 40-50\% during the relevant period of investigation. 
which reportedly was 15 to $20 \%$ lower than that for the comparable Smiths product. ${ }^{28}$ Smiths decided that it was time to take legal action.

As discussed earlier, antidumping duties provide a means for an incumbent to seek help from its government in warding off a foreign upstart. The incumbent accuses the foreign entrant of 'dumping' its product by selling it below the 'normal value' of the product in its home market. This strategy is relatively easier to employ when the foreign entrant is Chinese, because China's Protocol of Accession allows its trading partners to classify China as a 'non-market economy' (NME) when undertaking an antidumping investigation. ${ }^{29}$ This NME status often results in dumping margins much higher than those normally calculated by the investigating agency. This in turn can lead to much higher duties if material injury is found to have been caused by the dumped Chinese imports.

Smiths brought an antidumping case against 'Certain Cargo Scanning Systems' from China on 2 February 2009. Note that while Smiths' petition called for an investigation of all such products from China, the single relevant exporter was Nuctech. On 18 March 2009, the European Commission ('Commission') initiated an investigation into Nuctech's pricing of all cargo-scanning systems with $\mathrm{x}$-rays of $250 \mathrm{KeV}$ (kiloelectronvolts) or higher. ${ }^{30}$ The Commission established that the period of investigation (POI) would be from 1 July 2007 to 31 December 2008.

The Commission announced a preliminary $36.6 \%$ antidumping duty against Nuctech on 16 December 2009. The final duty was 34\% and came into force on 14 June 2010. With the imposition of the antidumping duties, Nuctech's pricing advantage over Smiths was reduced significantly. Smiths had managed successfully to use the European antidumping system to raise costs to a new Chinese rival as a concerted strategy to preserve its dominant position within the EU market.

Note that the emergence of antidumping measures in this instance was not part of a government-led strategic industrial policy. Instead, it was part of a firm-led initiative by the incumbent to ward off an entrant supported by industrial policy. The Commission, for its part, responded because it was forced to do so after receiving Smiths' petition and not necessarily as part of an active strategy to provide support to an embattled domestic producer.

\subsection{Chinese antidumping action in response}

After being hit with antidumping duties in an export market, note that Nuctech had at least two potential responses (which are not mutually exclusive). One option would be to lobby the Chinese government to file a WTO dispute against the

28 Ibid. at para. 83.

29 Protocol on the Accession of the People's Republic of China, para. 15.

30 Official Journal, L150/3 at para. 17; see also World Trade Organization, Semi-Annual Report under Article 16.4 of the Agreement, European Communities, G/ADP/N/188/EEC, 6 November 2009, at 3. 
government imposing the duties. A second option, discussed earlier, is to file its own antidumping case in its home market against its competitor in order to trigger tit-for-tat retaliatory duties. For now, we refrain from a discussion of other potential options. ${ }^{31}$

Had Nuctech pursued the first option, it would have lobbied the Chinese Ministry of Commerce ('MOFCOM') to file a WTO dispute against the EU for the imposition of its antidumping duties. In recent years, China has filed several such cases and prevailed on multiple occasions. ${ }^{32}$ However, this strategy is subject to several constraints and potential disadvantages. The most important of these is that the government must be able to craft a plausible argument that the Commission's actions were inconsistent with the EU's WTO obligations. If not, then no matter how hard Nuctech lobbies, MOFCOM might not be willing to expend resources for a case. Secondly, WTO disputes typically take multiple years to resolve. Firms, in the meantime, must be able to endure the impact of the higher antidumping duties, while their competitors benefit from the relative change in costs.

The second option, which can be executed as an alternative or in addition to the first option of a WTO dispute, was for Nuctech to initiate its own petition with the Chinese government to impose antidumping duties against Smiths in its own domestic market. This strategy has several advantages. First, the time necessary for a domestically administered antidumping case is far shorter than for a WTO dispute. Second, preliminary duties can be imposed before the conclusion of the case, meaning that the case will result in economic harm for its competitor and a change in the relative costs borne by each party much more quickly. Third, the case is decided by one's own national authorities rather than before an international panel. However, as was true of the first option, this strategy is also subject to certain constraints, and therefore, potential disadvantages. The most important of these is that one must be able to prove all of the required legal elements, as set forth in the ADA, for an antidumping duty. Otherwise, one's own government will not be able to impose antidumping duties in line with its WTO obligations. In addition, the domestic market must be large enough and its competitor's share within this market must be significant enough for the retaliatory antidumping duties to be sufficiently costly for one's competitor. Under this option (and unlike a successful outcome in the first option), the antidumping duties remain in place in the export market.

Nuctech decided to proceed with the second option. We do not know the extent to which the first option was also considered but it might not have been because

31 In subsection 5.1, we will draw attention briefly to other available options, such as limiting purchases through government procurement (for WTO members that are not party to the GPA).

32 See Appellate Body Report, European Communities-Definitive Anti-Dumping Measures on Certain Iron or Steel Fasteners from China, WT/DS397/AB/R, 15 July 2011, adopted 28 July 2011; Panel Report, European Union-Anti-Dumping Measures on Certain Footwear from China, WT/ DS405/R, 28 October 2011, adopted 22 February 2012. 
there was not an apparent WTO violation by the Commission. Pursuing an antidumping case against Smiths might also be a preferable option for the Chinese government if support for Nuctech was indeed part of a wider industrial policy seeking to expand domestic production in this relatively high value-added sector.

Nuctech filed a petition with MOFCOM for an antidumping investigation on x-ray scanners from the European Union on 28 August 2009, some seven months after the EU's own antidumping investigation. The relevant products were within the Chinese HS category 9022.19.10. MOFCOM determined that the period of investigation for dumping would be 1 January 2008 to 31 December 2008 while the POI for injury to the domestic industry making the like product would be 1 January 2006 to 31 December 2008. The only exporter investigated in the dumping case was Smiths. Smiths provided responses to MOFCOM's questionnaires that were used to determine the possible dumping margins.

The investigated products in China-X-ray Scanners included non-medical x-ray scanning equipment. Note that the products covered in the two antidumping cases are slightly different. The Chinese dumping notice stipulates that the product included systems using more than $100 \mathrm{KeV}$ while the EU announcement focuses on products with more than $250 \mathrm{KeV}$. This distinction will prove to be very important for the WTO litigation to come.

On 9 June 2010, MOFCOM announced a provisional dumping margin of $48.2 \%$ for Smiths. The pronouncement came only five days before the final antidumping duty of $34 \%$ announced by the European Commission in its own investigation of Nuctech. Seven months later, on 23 January 2011, MOFCOM announced a final antidumping duty of $33.5 \%$ for Smiths. ${ }^{33}$

What should we make of these patterns of counter-investigation and the nearly identical final duties imposed by China? Again, the process is foremost firm-driven. The move to bring antidumping duties within the arsenal of tools used to support Nuctech is one that was initiated by Nuctech itself. Faced with the prospect of being hurt by antidumping duties initiated by Smiths in the EU, Nuctech decided to fight back by petitioning to have similar duties imposed against Smiths in China.

While the actions in both Brussels and Beijing were clearly firm-driven, a question remains as to the role of the state in these actions. Were they simply passive actors? Did they take action only because they are required to do so in response to a domestic firm's petition for antidumping cases, as set forth in their own domestic laws and regulations? There are some hints to suggest that this indeed may have been the case. Nuctech relied upon the same Chinese law firm to defend its European and Chinese antidumping cases. When others have criticized the 
Chinese government for undertaking retaliatory antidumping cases, the offensive cases generally have been handled by one of the two dominant petitioners' law firms in China and not the law firm that handled Nuctech's cases. The fact that the follow-up case was not organized through the usual pattern may suggest that Nuctech (and/or its corporate law firm) was the key driver of the retaliatory action in China rather than the Chinese government.

However, given the close links between Nuctech and the government, it is difficult to rule out entirely the possibility that the Chinese government actively participated in the decision to file the antidumping case. If true, this pattern of government-sponsored tit-for-tat action is certainly not consistent with the spirit of the WTO system in which antidumping duties are to be used only in response to 'unfair' trading practices and not as a retaliatory measure against another country's trade action. To the extent that one has a problem with another country's trade actions, the WTO encourages the parties to resolve it diplomatically through consultations and turn to the Dispute Settlement Body if these consultations do not resolve the issue. ${ }^{34}$

Of course, we do not mean to necessarily single out China for potential bad behavior. As commentators have noted in Bown (2011), several WTO members have engaged in tit-for-tat retaliatory trade actions in response to trade remedies. To the extent that the actions are government-driven, the Chinese government is simply behaving in a similar manner to other major trading powers. Moreover, we cannot be certain that the actions here are government-sponsored. All we can note is that the firm that brought forward the action had close ties to the government and appears to have been supported through active strategic industrial policy. Most likely, both the firm and the government played active roles in triggering the problematic behavior that resulted in the WTO case - with the exact distribution between the two difficult for any outsider to discern.

Nevertheless, the overall point to note here is that the patterns of behavior are very different than those posited in the conventional account. Antidumping duties were not originally part of China's strategic industrial policy for championing a domestic firm in the x-ray scanners market. Antidumping duties probably entered into the Chinese government's calculus of how best to support Nuctech only after the EU imposed antidumping duties. The incorporation of antidumping duties into a government's industrial policy therefore may be a reactive development rather than one proactively crafted by economic policymakers. Furthermore, the actions of domestic firms and foreign governments may play a more important role in triggering this development than suggested in the existing literature.

This case study therefore highlights the fact that the conventional account is not the only path by which antidumping measures become enmeshed with a strategic 
industrial policy. The pathways are more varied. It is not always the case that the state simply takes the lead in using antidumping duties to protect an infant industry or salvage a dying one from import competition. This is even the case in China, where the state plays a relatively proactive role in the economy. Firms themselves may take the lead in introducing antidumping measures into the mix. This may be in reaction to another country's industrial policy or as a tit-for-tat response to another country's actions against it. Altogether, the dynamic between states and firms in drawing the two elements of antidumping and industrial policy into play is much more complex than has been acknowledged to date.

\section{How WTO litigation factors into this account: the China-X-Ray Equipment Panel Report}

This article so far has focused primarily on how antidumping measures and strategic industrial policy are intertwined. The interactions discussed in the earlier sections play out primarily in domestic administrative proceedings. Because actions taken by domestic antidumping authorities can be challenged before the WTO Dispute Settlement Body, decisions taken by the WTO have the potential to alter the impact of an antidumping measure taken in conjunction with a strategic industrial policy.

In section 4, we first provide an overview of the EU's complaint and how this case fits into the broader trend of WTO litigation against China. We then turn to discuss how the Panel resolved the specific issues alleged in the EU's complaint. We reserve our normative analysis of the Panel Report for section 5.

Our key point here is that WTO litigation can dramatically alter the benefits provided by antidumping duties to a party in a market where one (or more) of the players is supported by an industrial policy. The WTO litigation, as this case study demonstrates, does not tackle head-on the industrial policy instrument that the firms relied upon for its success (i.e., it does not address the government procurement and soft loan policies that Nuctech may have relied upon). Rather, at issue in the litigation are antidumping duties that arose as part of a tit-for-tat dynamic in reaction to the original industrial policy instruments.

The other point is that while the WTO dispute may be high-stakes litigation for the specific economic actors, the legal issues adjudicated are highly technical. They concern a range of treaty obligations that are both substantive and procedural in nature. This section demonstrates that it is partially through a process of wrangling over a series of technical legal issues concerning antidumping law that WTO members - and their domestic firms - seek to gain a relative advantage over each other in the competition for a global market.

\subsection{The EU's complaint}

Rather than pressure the EU to ratchet up tensions even further with yet another antidumping measure against a Chinese product, Smiths opted instead to push 
the EU to file a WTO complaint against China over MOFCOM's antidumping order. The Commission clearly agreed that there was sufficient evidence that MOFCOM had committed legal errors when undertaking its antidumping investigation that would cause China to be in violation of its WTO commitments. As we shall see below, the EU found numerous bases for alleged violations.

The EU requested consultations over China's antidumping duties against European x-ray security inspection equipment in late July 2011, six months after the final Chinese antidumping determination. Consultations were held in midSeptember 2011 and again in mid-October 2011 to no avail. On 8 December 2011, the EU requested that a Panel be established to adjudicate the dispute.

The EU complaint alleged violations of several provisions of the ADA, notably Articles 3.1, 3.2, 3.4, 6.2, 6.4, 6.5.1, 6.9, and 12.2.2. To simplify the discussion of the legal issues at stake, we group the EU's allegations into three categories of questions:

1. Did Chinese authorities properly perform the injury analysis required for an antidumping investigation, including inter alia appropriately defining the boundaries of the product scope of the investigated sector when undertaking its price effects analysis and its analysis of the state of the domestic industry?

2. Did Chinese authorities properly perform the causation analysis required for an antidumping investigation, including properly examining the causal relationship between dumped imports and injury and analyzing other known factors in its non-attribution analysis?

3. Did Chinese authorities fulfill various WTO requirements on transparency and due process in its handling of the antidumping case, including requirements concerning the treatment of non-confidential information, the disclosure of 'essential facts', and the publication of methodologies used in the investigation?

Before discussing how the Panel addressed these issues in particular, we wish to highlight how this case fits with the broader trend of WTO litigation concerning China. China has been a longstanding target of other countries' antidumping measures, accounting for a disproportionate share of global antidumping actions. ${ }^{35}$ Not surprisingly, China has filed many complaints at the WTO over foreign antidumping actions (and, more recently, countervailing duties) against Chinese exports. ${ }^{36}$ In fact, seven of China's 12 WTO dispute cases as of 2014 have involved these 'unfair' trade restrictions.

35 See various chapters of Bown (2011) and data available at Bown (2014).

36 For a list of completed cases filed against the European Union, see note 32 above. The cases filed against the United States and already completed include: Appellate Body Report, United StatesDefinitive Anti-Dumping and Countervailing Duties on Certain Products from China, WT/DS379/AB/R, 11 March 2011, adopted 25 March 2011; Panel Report, United States-Certain Measures Affecting Imports of Poultry from China, WT/DS392/R, 29 September 2010, adopted 25 October 2010; Appellate Body Report, United States-Measures Affecting Imports of Certain Passenger Vehicles and Light Tyre Trucks from China, WT/DS399/AB/R, 5 September 2011, adopted 5 October 2011; Panel 
In contrast, China is a relative newcomer among major trading countries in applying antidumping duties; however, in the past 15 years, it has emerged as a power in its own right. ${ }^{37}$ Through 2009, the actions of Chinese authorities on antidumping investigations went unchallenged at the WTO. None of the first 17 WTO complaints filed against China concerned antidumping. However, this pattern has shifted remarkably in recent years. Of the 14 complaints filed against China between 2010 and 2014, half have concerned China's antidumping regime. ${ }^{38}$ This case falls into this trend.

As mentioned, the Panel Report in China-X-Ray Equipment represents only the second time that the WTO dispute settlement body has issued a formal ruling on Chinese antidumping procedures. We expect several more WTO challenges and rulings in the near future given the importance of the Chinese market and the increasing willingness of China's trading partners to challenge its antidumping practices before the WTO. ${ }^{39}$ Just as American and European antidumping practices have been shaped through an iterative discourse with the WTO, so too will China's in the coming years.

On 26 February 2013, the Panel circulated its final report in the dispute. The EU prevailed on most, but not all of its claims against China. In the following subsection, we discuss the Panel's rulings on the three major sets of claims raised by the EU.

Report, United States - Anti-Dumping Measures on Shrimp and Diamond Sawblades from China, WT/ DS422/R, 8 June 2012, adopted 23 July 2012; Panel Report, United States-Countervailing Duty Measures on Certain Products from China, WT/DS437/ R, 14 July 2014; Appellate Body Report, United States-Countervailing and Anti-Dumping Measures on Certain Products from China, WT/ DS449/AB/R, 7 July 2014, adopted 22 July 2014. A Panel has been composed, as of this writing, in United States-Certain Methodologies and Their Application to Anti-Dumping Proceedings Involving China (DS471). Cases which did not proceed to the Panel stage include: United States-Preliminary Anti-Dumping and Countervailing Duty Determinations on Coated Free Sheet Paper from China (DS368) and European Union and Certain Member States-Certain Measures Affecting the Renewable Energy Generation Sector (DS452).

37 See Chandra (2011) for a useful general discussion about Chinese antidumping patterns as of 2009. Bown (2014) documents that there were 203 antidumping initiations by China between 1997 and November 2012, with 169 occurring since the PRC joined the WTO in 2001.

38 Besides China-X-Ray Equipment, six other claims have been filed. Of these, three have been completed. See China-GOES, note 7 above; Panel Report, China-Anti-Dumping and Countervailing Duty Measures on Broiler Products from the United States, WT/DS427/R, 2 August 2013, adopted 25 September 2013; Panel Report, China-Anti-Dumping and Countervailing Duties on Certain Automobiles from the United States, WT/DS440/R, 23 May 2014, adopted 18 June 2014; One dispute did not proceed to the Panel stage: China-Provisional Anti-Dumping Duties on Certain Iron and Steel Fasteners from the European Union (DS407). Two claims, both related to China-Measures Imposing Anti-Dumping Duties on High-Performance Stainless Steel Seamless Tubes ('HP-SSST') (DS454 and DS460), are ongoing, as of this writing.

39 Thomas Prusa and Edwin Vermulst discuss the subsequent Panel ruling in China-Boiler Products (DS427) in this volume. Another Panel report has been issued in China-Autos (US) (DS440), while the China-HP-SSST disputes are ongoing as of this writing. See note 38 above. 


\subsection{Injury analysis-ADA Articles 3.1, 3.2, and 3.4}

The EU claimed that MOFCOM, when examining price undercutting and price suppression ${ }^{40}$ as part of its injury analysis, did not base its findings 'on an objective examination of positive evidence' and consequently, China had violated its obligations under Articles 3.1 and 3.2 of the ADA. ${ }^{41}$ At the heart of this debate is the question of how an investigating authority is to segment the product market/ industry when performing the price analysis necessary to determine injury.

MOFCOM made its finding of price undercutting and price suppression by comparing the annual weighted average unit prices of all dumped imports with the annual weighted average unit process of all domestic sales. ${ }^{42}$ In examining whether Nuctech suffered injury as a result of Smiths' actions, MOFCOM did not request Nuctech to provide transaction-specific data or data on a model-bymodel basis. ${ }^{43}$ The EU noted that there are, however, important differences between 'low energy' and 'high energy' scanners, and that MOFCOM erred by not taking these differences into account. ${ }^{44}$ In particular, the EU noted that there were no exports of 'high energy' scanners from the EU during the period of investigation. ${ }^{45}$ China's failure to take this fact into account, the EU contended, meant that the price analysis methodology undertaken by MOFCOM was flawed since inadequate steps were taken to ensure that the prices compared were in fact comparable. ${ }^{46}$

China argued that MOFCOM did consider Smiths' arguments concerning 'high energy' and 'low energy' scanners and concluded that they were 'like' products. ${ }^{47}$ It cited the prior WTO ruling in EC-Salmon (Norway) ${ }^{48}$ noting that so long as an investigating authority finds the broad basket of goods under investigation and the broad basket of domestic goods to be 'like', this is sufficient; it need not be the case that each good within the basket of domestic goods is 'like' each of the products under investigation. ${ }^{49}$ Furthermore, it noted that Smiths had only raised the issue of comparability in the context of the scope of products under investigation, but

40 Note that the parties disagreed as to whether MOFCOM made a finding of price suppression or price depression. The EU argued that MOFCOM's finding was one of price depression, while China argued that it was one of price suppression. The Panel found it unnecessary to decide this issue, noting that if MOFCOM maintains that it made a finding of price suppression, then the Panel would proceed on the basis of that label. See Panel Report, China-X-Ray Equipment, paras. 7.20, 7.28, and 7.527.54. This article follows the same approach.

41 Ibid., para. 7.30.

42 Ibid., para. 7.34

43 Ibid. para. 7.36.

44 Ibid., para. 7.16.

45 Ibid., para. 7.30 .

46 Ibid., para. 7.16.

47 Ibid., para. 7.65 .

48 Panel Report, European Communities - Anti-Dumping Measure on Farmed Salmon from Norway, WT/DS337/R, adopted 15 January 2008, and Corr.1.

49 Specifically, China made reference to paras. 7.13-7.76 of the Panel Report in EC-Salmon (Norway). 
not as part of the price undercutting or suppression analysis. ${ }^{50}$ Nor had Smiths provided the data necessary for MOFCOM to undertake a model-by-model price comparison. Thus, China argued that given the circumstances, MOFCOM's use of the weighted average methodology was reasonable and appropriate. ${ }^{51}$

The Panel rejected China's arguments and sided with the EU. It did not accept China's argument that its approach was reasonable given the circumstances, noting that even if Smiths had provided such data, it would have been impossible for MOFCOM to perform the proper analysis because it had not requested such pricing data from Nuctech. ${ }^{52}$ Because MOFCOM had failed to demonstrate its willingness to undertake the proper methodological adjustments (regardless of whether data were forthcoming or not), the Panel concluded that 'MOFCOM's price undercutting and price suppression analyses ... were not based on an objective examination of positive evidence'. ${ }^{53}$ Consequently, the Panel ruled that 'China acted inconsistently with Articles 3.1 and 3.2 of the [ADA] by failing to ensure that the prices it was comparing as part of its price effects analysis were actually comparable'. 54

In addition, the EU asserted that China had further erred in its injury analysis because MOFCOM did not base its finding on positive evidence about the state of the domestic industry. ${ }^{55}$ Consequently, the EU alleged that China also violated its obligations under Articles 3.1 and 3.4 of the ADA. In particular, the EU drew attention to discrepancies between the data cited by MOFCOM and (1) the data supplied by Nuctech in its petition and questionnaire, and (2) the data in publicly available documents, such as Nuctech's parent company annual reports and agency filings. 56

The Panel sided with China on this issue. While acknowledging that there were indeed discrepancies, the Panel noted that the relevant question was 'whether the European Union has established a prima facie case that the evidence upon which MOFCOM relied in making its injury determination was not of an affirmative, objective and verifiable character and was not credible'. ${ }^{57}$ The Panel held that the EU had failed to present adequate evidence to make this case. In particular, the Panel noted that it was not convinced by the EU's suggestion that the provided data could not have been modified properly, and that the EU had not demonstrated that the data, assuming they were modified, were not credible. ${ }^{58}$

50 Panel Report, China-X-Ray Equipment, para. 7.40.

51 Ibid., para. 7.93.

52 Ibid., para. 7.94.

53 Ibid., para. 7.97.

54 Ibid.

55 Ibid., para. 7.98.

56 Ibid., para. 7.141.

57 Ibid., para. 7.149.

58 Ibid., para. 7.167. 
The EU further alleged that China had acted inconsistently with ADA Articles 3.1 and 3.4 because MOFCOM did not examine all of the factors listed in Article 3.4 as required for the injury analysis. ${ }^{59}$ In particular, the EU drew attention to the fact that MOFCOM had failed to examine 'the magnitude of the margin of dumping'. ${ }^{60}$ In response, China noted that MOFCOM had listed the magnitude of the margins of dumping for Smiths and other producers in two sections of its final determination, thereby suggesting that MOFCOM had indeed considered this factor. ${ }^{61}$ The Panel rejected China's argument by noting that a mere listing of the facts was insufficient evidence of consideration of the factor by the investigating authority. ${ }^{62}$ Therefore, the Panel also concluded that China had acted inconsistently with ADA Articles 3.1 and 3.4 because MOFCOM failed to demonstrate that it had evaluated the magnitude of the margins of dumping in its injury analysis. ${ }^{63}$

Finally, the EU noted that MOFCOM failed to provide a compelling explanation for why it found injury to the domestic industry when 9 of the 16 indicia of the state of the industry were found to be positive rather than negative. ${ }^{64}$ The Panel agreed with the EU that MOFCOM's treatment of these 16 factors 'did not reflect an objective examination of the evidence'. ${ }^{65}$ Consequently, it decided that China had also violated its obligations under Articles 3.1 and 3.4 of the ADA on this basis. ${ }^{66}$ The Panel's view was that rather than simply listing the factors and the trends observed, MOFCOM should have explicitly analyzed each of the 16 factors and assigned them appropriate weights in its overall injury analysis. ${ }^{67}$ The Panel held that MOFCOM's error was one of methodology rather than substantive explanation; the Panel did not think it necessary to decide whether MOFCOM was obliged to provide a more compelling explanation than that which had been given. ${ }^{68}$

To summarize, with respect to the injury analysis, the Panel found that several of MOFCOM's actions were inconsistent with China's treaty obligations as set forth in the ADA. The most significant findings were those concerning the industry definition used by MOFCOM. We will return to examine this issue in our analysis in section 5 .

59 Ibid., para. 7.178.

60 Ibid.

61 Ibid., para. 7.182 .

62 Ibid., para. 7.183 .

63 Ibid., para. 7.185.

64 Ibid., paras. 7.210 and 7.214 .

65 Ibid., paras. 7.215-7.216.

66 Ibid., paras. 7.215-7.216.

67 Ibid., para. 7.215 .

68 Ibid. 


\subsection{Causation analysis-ADA Articles 3.1 and 3.5}

The EU also argued that China violated Articles 3.1 and 3.5 of the ADA 'because MOFCOM failed to make an objective determination, on the basis of all relevant evidence before it that the dumped imports were, through the effects of dumping, causing injury'. ${ }^{69}$ In other words, the EU suggested that shortcomings in MOFCOM's injury analysis also led it to perform an improper causation analysis.

The Panel ruled that MOFCOM had erred in its price analyses because it failed to take into account differences across the products (i.e., between 'high energy' and 'low energy' scanners), and the Panel agreed that 'flaws in the price effects analysis also undermine MOFCOM's conclusion on the causal link between the subject imports and the injury suffered by the industry'. ${ }^{70}$

Again, the issue of industry definition and proper product differentiation proves fatal for China. Not only did MOFCOM's actions here cause China to be in violation of its WTO obligations concerning the ADA's requirements for the injury analysis, but they also led to violations of China's obligations concerning how the causation analysis should be performed.

The Panel also found MOFCOM's conclusion that dumped imports were the only cause of injury over the period of investigation to be problematic. Given that the price of the domestic good continued to be lower than that of imports, the Panel asked why couldn't Nuctech simply increase its prices at least to the level of Smiths' prices. ${ }^{71}$ Was it the case that other factors, besides dumping, were also at work in causing Nuctech's injury? The fact that MOFCOM did not address this issue in its final determination, the Panel found, suggested that MOFCOM 'did not conduct an objective examination of the evidence' in violation of ADA Articles 3.1 and 3.5.72

In addition, the EU also argued that MOFCOM failed to consider the relevance of other known factors as part of its non-attribution analysis. WTO law requires that, in the course of determining whether dumped imports are causing injury to the domestic industry, the investigating authority is obligated to "examine any known factors other than the dumped imports which at the same time are injuring the domestic industry'. ${ }^{73}$ The EU alleged that MOFCOM ignored five known factors raised by interested parties, 'namely (i) the impact of the global financial crisis; (ii) fair competition between Nuctech and other producers; (iii) Nuctech's aggressive business expansion; (iv) Nuctech's aggressive pricing policy; and (v) Nuctech's start-up situation' ${ }^{74}$ China, in turn, argued that before MOFCOM was obliged to consider any of these known factors, Smiths was obliged to

69 Ibid., para. 7.218.

70 Ibid., para. 7.239 .

71 Ibid., paras. 7.244-7.247.

72 Ibid., para. 7.248.

73 WTO Anti-Dumping Agreement, Article 3.5.

74 Panel Report, China-X-Ray Equipment, para. 7.264. 
present evidence that these factors were causing injury to Nuctech and had failed to do so. 75

With respect to the first and last of the five factors put forward by the EU, the Panel sided with China. It noted that MOFCOM's handling of the factors was sufficient given the arguments put forward by Smiths. ${ }^{76}$ The Panel sided with the EU on the three remaining issues. It concluded that 'MOFCOM did not adequately engage with the evidence and arguments submitted by Smiths to the effect that Nuctech could not offer the same products as Smiths, or could not offer products of the same quality'. ${ }^{77}$ The Panel further determined that MOFCOM should have also considered the impact of Nuctech's capacity expansion and its rising inventories, ${ }^{78}$ as well as investigated further the possibility that Nuctech was pursuing an aggressive pricing strategy as alleged by Smiths. ${ }^{79}$

Overall, although the Panel did not agree with all of the EU's arguments concerning causation-related claims, it found several of them to be valid. Specifically, the Panel specified three shortcomings: (1) MOFCOM had relied on a WTO-inconsistent price effects analysis and injury findings for its causation analysis; (2) it 'failed to consider certain "known factors"; and (3) it "failed to consider evidence relating to other factors that it did explicitly consider, in its non-attribution analysis' ${ }^{80}$ Consequently, the Panel concluded that China had acted inconsistently with its WTO requirements, as set forth in ADA Articles 3.1 and 3.5, in determining that Smiths' dumping had caused injury to Nuctech.

\subsection{Issues concerning transparency and due process-ADA Articles 6.5, 6.9 , and 12.2}

The EU also raised a series of issues alleging procedural shortcomings by MOFCOM. First, the EU challenged MOFCOM's handling of non-confidential information submitted by Nuctech. A petitioner in an antidumping case often must submit information that it considers confidential. To ensure that the respondent has a chance to file an effective rebuttal, WTO law requires that ' $\mathrm{t}]$ he authorities shall require interested parties providing confidential information to furnish non-confidential summaries ... in sufficient detail to permit a reasonable understanding of the substance of the information submitted in confidence' ${ }^{81}$

75 Ibid., para. 7.266 .

76 Ibid., paras. 7.268-7.271 and 7.292-7.296.

77 Ibid., para. 7.280 .

78 Ibid., paras. $7.285-7.286$.

79 Ibid., para. 7.291. In response to China's argument that Smiths had not provided evidence of Nuctech's pricing strategy, the Panel responded that 'given the highly confidential nature of a company's pricing strategy, any evidence from a competitor regarding the existence of a particular pricing policy will necessarily be circumstantial'. In the Panel's view, Smiths had presented such circumstantial evidence to MOFCOM in the form of a pricing study.

80 Ibid., paras. 7.297-7.299.

81 WTO Anti-Dumping Agreement, Article 6.5.1. 
The law contains an exception for 'exceptional circumstances' in which 'such information is not susceptible of summary'. ${ }^{82}$ When invoked, the authorities must provide a statement explaining why summarization is not possible. ${ }^{83}$

Smiths exported four models of x-ray scanners to China. In the non-confidential summary provided to Smiths, MOFCOM had allowed Nuctech to designate the models that Nuctech alleged were being dumped as simply 'Model 1' and 'Model 2'. China contended that Smiths, on the basis of the information provided, should have been able to figure out the two models being referenced since Smiths exported only four models. ${ }^{84}$ The EU, however, argued that this labeling failed to meet the requirements of Article 6.5.1.85 The Panel agreed with the EU, noting that it was the investigating authority's responsibility to require 'the interested party furnishing the information to provide a summary thereof, rather than requiring the other party to infer, derive, or piece together a possible summary of the confidential information'. ${ }^{86}$ The Panel also upheld the EU's claim that the non-confidential summaries provided by Nuctech of relevant Exhibits and responses to questions were also inadequate. ${ }^{87}$

The EU also raised an objection to MOFCOM's failure to provide a summary of certain confidential information submitted by the Public Security Bureau (PSB) of the Civil Aviation Administration. China claimed that MOFCOM had received an oral explanation from the PSB about why its information could not be summarized and argued that it did not provide this explanation because the reasons themselves were confidential. ${ }^{88}$ The Panel rejected China's argument, stating that China nevertheless should have explicitly invoked the 'exceptional circumstances' exception and provided a 'statement of the reasons why summarization of the underlying confidential information was not possible'. ${ }^{89}$

Second, the EU claimed that MOFCOM failed to disclose certain essential facts that formed the basis of its decision to apply definitive antidumping duties. ${ }^{90}$ The EU accused MOFCOM of inadequate disclosure in four instances. ${ }^{91}$ The Panel

82 Ibid.

83 Ibid.

84 Panel Report, China-X-Ray Equipment, para. 7.332.

85 Ibid., para. 7.331 .

86 Ibid., para. 8.332 (quoting China-GOES, para. 7.202).

87 Ibid., paras. 7.338-7.343 and 7.348-7.364. However, the Panel rejected the EU's claims with respect to certain Attachments in Nuctech's questionnaire response. See ibid., paras. 7.344-7.347.

88 Ibid., paras. 7.366-7.369

89 Ibid., para. 7.371.

90 Ibid., para. 7.378 .

91 These alleged failures to disclose involved: (1) the underlying data and methodology used by MOFCOM in its price analysis; (2) adjustments made by MOFCOM to the export price in respect of sales to an affiliated distributor; (3) the data and adjustments applied by MOFCOM in determining Smiths' margin of dumping; and (4) the facts available used by MOFCOM to establish the residual antidumping rate. See ibid. 
accepted the EU's arguments in three of the four instances. ${ }^{92}$ In two of these instances, the Panel decided that MOFCOM was not obliged to disclose as much as the EU had contended, but that MOFCOM's disclosures were nevertheless inadequate. ${ }^{93}$ The Panel consequently held that China was in violation of its obligations under Article 6.9 of the ADA.

Finally, the EU challenged China on the basis of shortcomings concerning the public notice provided by government authorities. The chapeau of Article 12.2 of the ADA provides that the government, when issuing any preliminary or final determination, 'shall set forth ... in sufficient detail the findings and conclusions reached on all issues of fact and law considered material by the investigating authorities'. Furthermore, the first sentence of ADA Article 12.2.2 provides that the 'public notice of conclusion ... of an investigation in the case of an affirmative determination providing for the imposition of a definitive duty ... shall contain, or otherwise make available through a separate report, all relevant information on the matters of fact and law and reasons which have led to the imposition of final measures'. The second sentence then provides that 'the notice or report shall contain ... reasons for the acceptance or rejection of relevant arguments or claims made by exporters or importers'.

The EU made two sets of claims regarding Chinese violations of Article 12.2.2. The EU claimed that MOFCOM's public notice failed to include relevant information concerning the price effects analysis, the margin of dumping established for Smiths, and the residual antidumping duty. ${ }^{94}$ The Panel found that MOFCOM had failed to 'provide relevant information regarding its price effects analysis and its determination of the residual rate'. ${ }^{95}$ However, it rejected the EU's claims that calculations of the dumping margin and residual rate must be included in the public notice. ${ }^{96}$ On this last question, the Panel's holding falls squarely in line with the prior one established in the China-GOES case. $^{97}$

The EU also alleged that MOFCOM violated Article 12.2.2 of the ADA by not explaining in its public notice why it rejected arguments made by Smiths concerning

92 Ibid., paras. 7.411, 7.426, and 7.421. The one instance where the Panel rejected the EU's argument altogether concerned the EU's claim that MOFCOM had failed to disclose essential facts pertaining to the basis on which the affiliated distributor adjustment to export price was made. Ibid., para. 7.415.

93 These two instances are as follows: First, the Panel decided that MOFCOM was not obliged to disclose the actual calculations of Smiths' dumping margin to Smiths, but that it should have disclosed 'the price and adjustment data underlying its determination of Smiths' margin of dumping'. Ibid., para. 7.421. Second, the Panel decided that MOFCOM had sufficiently disclosed the facts behind MOFCOM's decision to apply the 'facts available' approach, but that it had not disclosed the essential facts forming the basis for its calculation of the residual rate. Ibid., paras. 7.424 and 7.426.

94 Ibid., para. 7.456 .

95 Ibid., paras. 7.463, 7.467-7.468, and 7.470.

96 Ibid., paras. 7.464, 7.466, and 7.470.

97 Panel Report, China-GOES, para. 7.333. 
three different issues. ${ }^{98}$ The second sentence of Article 12.2.2 requires that the investigating authority include its rationale for acceptance or rejection of the parties' arguments in its public notice, and the Panel emphasized that 'it is particularly important that the "reasons" ... be set forth in sufficient detail to understand why their arguments or claims were treated as they were, and to assess whether or not the investigating authority's treatment of the relevant issue was consistent with domestic law and/or the WTO Agreement'. ${ }^{99}$ The Panel then found that MOFCOM violated this requirement in one of the three instances, where MOFCOM never addressed an argument raised by Smiths concerning the armslength nature of its sales to affiliated distributors in its final determination. ${ }^{100}$ However, the Panel declared that with respect to arguments raised in the other two instances, either the MOFCOM's explanation was sufficient ${ }^{101}$ or the EU had failed to establish a prima facie case for its claim. ${ }^{102}$

Overall, the EU successfully prevailed in a number of transparency-related claims against China. Ranging from the treatment of non-confidential summaries to the completeness of the public notice provided, the WTO Panel Report draws attention to deficiencies in the due process and other procedural protections afforded in administrative litigation before Chinese government authorities. These may prove relatively straightforward for MOFCOM to fix, but in the meantime, they pose two consequences. The first is that China will need to undo its antidumping duties against Smiths while MOFCOM engages in these procedural fixes. The second is that future respondents before MOFCOM will have access to greater information - an implication that we will explore in greater detail in the next section.

\subsection{Epilogue}

As the above case study demonstrates, WTO litigation provides a means for a WTO member to alter the impact of antidumping duties used to support (or combat) an exporter supported by industrial policy. For this strategy to be effective, however, the WTO member must be able to allege that its trading partner committed certain WTO-inconsistent acts when imposing the antidumping duties. Inexperienced investigating authorities more commonly commit such acts,

98 These are arguments made by Smiths concerning: (1) the treatment of domestic sales to affiliated distributors, (2) the credibility of certain injury data and other injury issues, and (3) the existence of any causal link between dumped imports and injury to the domestic industry. Panel Report, China-X-Ray

Equipment, para. 7.471.

99 Ibid., para. 7.472.

100 Ibid., para. 7.478 .

101 Ibid., para. 7.483 .

102 Ibid., paras. 7.486 and 7.490 . 
although they are by no means the only ones. ${ }^{103}$ The EU, in this instance, successfully challenged several of MOFCOM's acts. China, by contrast, had chosen earlier not to challenge any of the Commission's acts.

China also decided not to appeal the Panel Report. The Dispute Settlement Body adopted it on 24 April 2013. Ten months later, on 26 February 2014, MOFCOM terminated the antidumping duty on Smiths x-ray scanners, thereby bringing China into full compliance with the Panel ruling. Table 1 provides a summary of the full timeline of the two antidumping cases as well as the WTO case.

WTO litigation therefore serves as a mechanism to dramatically alter the payoffs from employing antidumping duties in support of an industrial policy. Although the issues litigated are highly technical, at the end of the day the litigation result provided Smiths with a clear advantage. Without the WTO case, both Smiths and Nuctech would continue to face temporary trade barriers in a key export market. The titfor-tat antidumping measures seek to neutralize each other out, thereby allowing any industrial policy at work to continue to exert its impact on the global market. The WTO ruling, however, changes this dynamic. As of now, only the EU continues to maintain antidumping duties in an effort to thwart Nuctech from gaining a greater foothold in Smiths' home market. To the extent that the Chinese government may be relying upon industrial policy instruments to support Nuctech, that arsenal does not, at present, include antidumping duties. WTO litigation proved to be an effective means for the EU to undo Chinese efforts to retaliate against Smiths and reduce the payoffs from a Chinese industrial policy.

However, the saga may not have come to an end. MOFCOM has announced that it plans to reopen an investigation on x-ray equipment from the EU. The prospect of continuing tit-for-tat antidumping sanctions between the EU and China lingers on the horizon.

What the China-X-Ray Equipment case study demonstrates, therefore, is that the relationship between antidumping duties and industrial policy is much more complex than that posited in the conventional account. A back-and-forth dynamic exists between states and firms, and between litigation before domestic administrative agencies and the WTO. Minutiae of WTO law, as discussed in this section, can factor in this dynamic, as each side seeks to gain a relative advantage over the other in the quest for a growing global market.

\section{Analysis and implications}

The China-X-Ray Equipment case demonstrates that the alternative mechanisms advanced in section 2 are not merely theoretical. Antidumping duties do actually

103 Actions taken by investigating authorities in both the US and EU, two established players, have also been successfully challenged in a number of cases before the WTO, particularly with respect to legal issues requiring judicial clarification/elaboration. 
Table 1. Timeline of Relevant X-ray Scanner Antidumping Cases between the EU and PRC

\begin{tabular}{|c|c|c|c|c|c|c|c|c|c|}
\hline & Product & $\begin{array}{l}\text { HS codes } \\
\text { (Investigated } \\
\text { products fall within } \\
\text { these codes) }\end{array}$ & $\begin{array}{l}\text { Petitioning } \\
\text { firm }\end{array}$ & $\begin{array}{l}\text { Investigated } \\
\text { exporter }\end{array}$ & $\begin{array}{l}\text { Petition } \\
\text { filing } \\
\text { date }\end{array}$ & $\begin{array}{l}\text { Preliminary } \\
\text { AD date (duty } \\
\text { imposed) }\end{array}$ & $\begin{array}{l}\text { Final AD } \\
\text { date (duty } \\
\text { imposed) }\end{array}$ & $\begin{array}{l}\text { Current status (June } \\
\text { 2014) }\end{array}$ & Notes \\
\hline China & $\begin{array}{l}\text { X-ray Security } \\
\text { Inspection } \\
\text { Equipment' }\end{array}$ & 9022.19 .10 & Nuctech & Smiths & $\begin{array}{l}28 \text { Aug. } \\
2009\end{array}$ & $\begin{array}{l}9 \text { June } 2010 \\
(48.2 \%)\end{array}$ & $\begin{array}{l}23 \text { Jan. } \\
2011 \\
(33.5 \%)\end{array}$ & $\begin{array}{l}\text { Terminated on } 26 \text { Feb. } \\
2014 \text { in response to } \\
\text { DSB Panel Report (but } \\
\text { investigation reopened } \\
\text { after DSB Panel } \\
\text { Report) }\end{array}$ & $\begin{array}{l}\text { Systems } \\
\text { using }>100 \\
\mathrm{KeV}\end{array}$ \\
\hline EU & $\begin{array}{l}\text { Certain Cargo } \\
\text { Scanning } \\
\text { Systems' }\end{array}$ & $\begin{array}{l}9022.19 .00 .00 \\
9022.29 .00 .10 \\
9027.80 .17 .10 \\
9030.10 .00 .91 \\
8705.90 .90 .10\end{array}$ & Smiths & Nuctech & $\begin{array}{r}2 \text { Feb. } \\
2009\end{array}$ & $\begin{array}{l}16 \text { Dec. } 2009 \\
(36.6 \%)\end{array}$ & $\begin{array}{l}14 \text { June } \\
2010 \\
(34 \%)\end{array}$ & Remains in place & $\begin{array}{l}\text { Involves only } \\
\text { cargo scan- } \\
\text { ning } \\
\text { systems } \\
>250 \mathrm{KeV}\end{array}$ \\
\hline
\end{tabular}


become enmeshed with industrial policy in the manner described earlier-one in which firms take the lead and governments react to support domestic producers and retaliate against their trading partners. In section 5 , we turn to analyze the legal and economic implications that arise from the specific case study at hand.

Our analysis emphasizes two key findings: First, we suggest that the strategy of deploying antidumping duties as a supplemental instrument in support of a strategic industrial policy can prove effective, at least as far as near-term trade flows are concerned. However, we posit that the strategy may only work under certain conditions. Second, we suggest that the Panel's ruling in the China-X-Ray Equipment case is significant because it attempts to provide greater clarity as to what domestic authorities must do when comparing prices across 'like' products during the course of an investigation. Manipulations of such calculations, as we shall see, can serve as a means to raise antidumping tariffs to effectuate an industrial policy. While the Panel Report provides greater clarity as to what is and is not permissible, we argue that several questions remain unresolved in the aftermath of the Panel's ruling.

\subsection{Are antidumping measures an effective supplemental instrument for strategic industrial policy? Evidence from the Nuctech-Smiths dispute}

We have suggested that the Chinese government may be using trade remedy laws to support a broader industrial policy goal for the x-ray scanner market, though it is unclear whether this is in reaction to a firm-led initiative or part of a direct partnership between the government and firm. Regardless, what is clear is that the Chinese government took actions in contravention of its WTO obligations that benefited its domestic producer through antidumping duties. What triggered this action was the need to react forcefully to its trading partner's antidumping measures designed to prevent a Chinese upstart from expanding into an established high-tech market.

Can such a strategy work? Past studies have shown that by raising tariffs, antidumping duties can be an effective tool in reducing imports from a specific foreign competitor. ${ }^{104}$ They are more effective in helping the threatened domestic industry when there are no alternative foreign sources easily available to simply replace the targeted imports. But can they also be an effective tool at countering the antidumping duties that a trading partner has imposed against a domestic producer supported through a strategic industrial policy? If so, one should see evidence in trade flows of $\mathrm{x}$-ray scanners between the EU and China.

104 See, for example, Konings et al. (2001), Malhotra and Malhotra (2005), as well as selective case studies in Finger and Nogues (2005). Note that it is not always the case that trade remedies are effective. Trade remedies typically raise duties on imports from a subset of trading partners while others still enjoy most favored nation tariff rates. Therefore, past studies have also shown that in some instances, a selective increase in tariffs can result in simply shifting imports from one source to another without substantially helping domestic industry. See, for example, Prusa (1997) and Charnovitz and Hoekman (2013). 
One of the case's complications is that a number of potentially disparate products fall within this HS category. ${ }^{105}$ This is in itself not unusual in antidumping cases. Many countries investigate imports based on detailed product descriptions that do not necessarily line up one-to-one with a single HS code.

In this particular instance, the Chinese eight-digit HS category (9022.19.10) identified in the investigation includes not only products such as security equipment to examine large truck containers and railway cars but also airport hand luggage scanners. Whether these are a single 'like' product is at the heart of the WTO dispute, which will be discussed in more detail in the next subsection.

Nevertheless, we can still examine the relevant data to discern what impact antidumping duties had on trade flows between the EU and China in the relevant eight-digit product categories in each market. ${ }^{106}$ Table 2 shows that in the years preceding the antidumping investigations in each market, both the EU and China were expanding their exports of x-ray scanners into the other's market.

Let us first examine the inroads made by Nuctech into the European market. Official European data for HS category 9022.19.00 (the most relevant individual category for the case given the EU's eight-digit coding) shows a dramatic increase in Chinese exports: a near tripling of import value from $€ 3.96$ million in 2005 to $€ 11.87$ million in 2008 , the year before the antidumping case was initiated in the EU. ${ }^{107}$ Nuctech's success in Europe prompted Smiths to file its antidumping case, triggering the chain of events at issue in this case.

While Nuctech was making progress penetrating Smiths' once dominant hold of the European market, Smiths was not simply standing still. It is important to note this is not the story of yet another once-dominant Western firm simply being pummeled globally by a new low-cost Chinese entrant supported by industrial policy. In the years prior to the anti-dumping case, Smiths too was making inroads into the Chinese market that Nuctech dominated. UN Comtrade statistics for China show that the total import value from the EU for the eight-digit product category (HS 9022.19.10) doubled from \$13.1 million in 2005 to $\$ 26.6$ million in 2008, almost all of which came from Germany (the production home of the x-ray scanners named in the petition).

105 This refers to the coding developed under the Harmonized System maintained by the World Customs Organization used to account for trade in goods. The codes are organized into categories that cascade from two digits onward. Up through six digits, the codes are standardized across WTO members. Beyond six digits, however, WTO members are allowed to create their own categories. Antidumping measures can be imposed at levels much more granular than the six-digit level, and in this particular instance, China's antidumping measure was imposed at the eight-digit level.

106 Our thanks to Chad Bown for providing us with the eight-digit trade flows for these categories, which are not available in the public version of the UN Comtrade database.

107 Note that these data are similar but not identical to those noted in the questionnaire response as reported in the EU Official Journal. The EU Official Journal highlighted the fact that Chinese imports' share of the EU market for the specific investigated product (which is more narrow than the 9022.19.00 category) increased dramatically-rising from $15-25 \%$ in 2004 to $40-50 \%$ during the investigation period (1 July 2007 to 31 December 2008). See Official Journal, L150/9, at para. 77. 


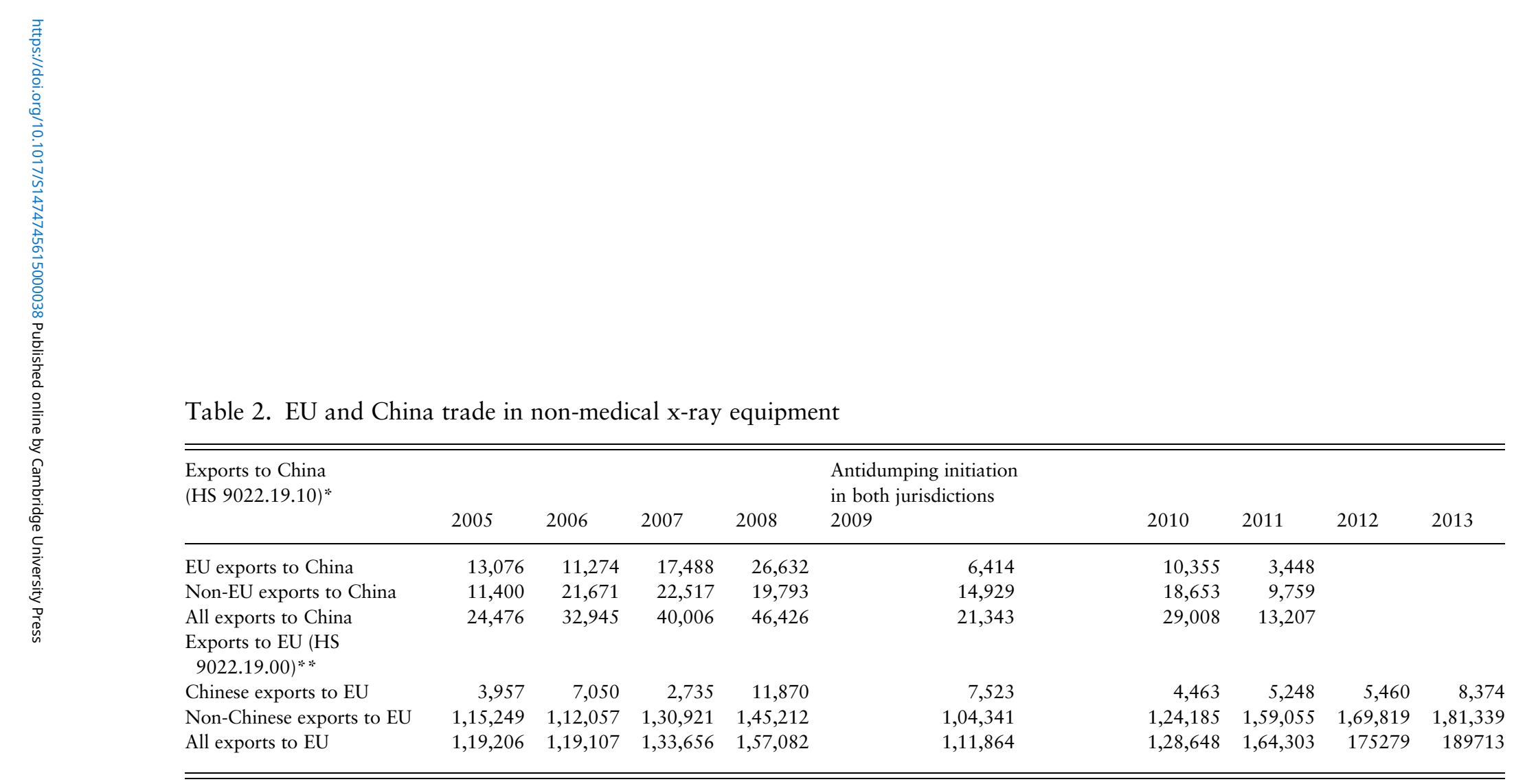

Table 2. EU and China trade in non-medical x-ray equipment

Notes: " Source: UN Comtrade, value in thousands of US\$

* "Source: Eurostat, value in thousands of euros 
The data reported in the preliminary Chinese antidumping decision provide additional details for the more narrow set of investigated products within the eight-digit HS category. It notes that investigated EU imports from Germany rose $87 \%$ from 179 units in 2006 to 336 units in $2008 .{ }^{108}$ It also reports that EU imports' share of the Chinese market for the investigated products rose from $11 \%$ in 2006 to $16 \%$ in $2008 .{ }^{109}$ The relatively modest increase in market share, despite the significant increase in the volume of European imports, suggests that overall Chinese demand for these products must have been increasing fairly rapidly in this period. This should not be surprising, given China's heavy infrastructure spending in the mid to late 2000s.

The preliminary Chinese antidumping decision also notes some import pricing data for the period of investigation that were important in the Panel's decision. The average unit value reported by MOFCOM for investigated EU products rose in every year of the investigation: RMB 463,520 in 2006 to RMB 468,313 in 2007 to RMB 504,767 in $2008 .{ }^{110}$ In contrast, the report notes a fall in domestic prices of the similar goods of $49 \%$ from 2006 to 2007 and a further decrease of $47 \%$ in 2008.111

In short, UN Comtrade data and China's own report suggest the following important patterns for the three years prior to the antidumping investigation: (1) the price (unit value) of EU x-ray scanners was increasing in China; (2) Chinese prices (unit value) for the $\mathrm{x}$-ray scanners were falling; and (3) EU exports to China nonetheless were increasing. (Note that this combination of factors lies at the heart of the arguments about whether EU imports could be causing injury to Chinese products.)

What we see from the trade flow statistics in the years prior to the antidumping investigation is that both European and Chinese producers appeared to be benefiting from expanded opportunities created by trade. At the same time that exports of European x-ray scanners to China were increasing dramatically, Chinese x-ray scanners were also making strong progress into the European market. Table 2 shows that between 2005 and 2008, EU exports to China of the relevant product category expanded by $\$ 13.5$ million while Chinese exports to the EU expanded by $€ 7.9$ million. ${ }^{112}$

108 Ministry of Commerce, 中华人民共和国商务部关于原产于欧盟的进口X射线安全检查设备反倾 销调查的初步裁定 [Preliminary Determination of the Ministry of Commerce of the People's Republic of China Concerning Anti-Dumping Duties on Imports of X-Ray Security Equipment from the European Union], 2009 Circular No. 63 at p. 15. Comtrade data for the broader category notes a $131 \%$ increase in the value of German imports of HS 9022.19.10 for the same period. This likely reflects that the investigated product is only a subset of the official eight-digit HS category. It may reflect an increase in the unit price of German exports in the same period, which we will discuss below.

109 Ibid.

110 Ibid., at p. 16.

111 Ibid.

112 The exchange rate was calculated using an average of the monthly 2008 dollar-euro exchange rate. Note that slight differences in the product coverage across the statistics do not allow for these to be exact comparisons. 
Nevertheless, this is clearly not how Smiths saw the situation. Despite the fact that its exports to China were increasing dramatically, it was concerned about the threat it faced from Nuctech in its home market. Smiths was determined to lessen pressure from its Chinese competitor by filing the antidumping action against Nuctech in the EU.

The efforts by Smiths and the Commission to restrict Nuctech's exports to the EU followed a period when the Chinese market was relatively open to EU X-ray scanner exports. Chinese government agencies had procured significant volumes of x-ray scanning equipment from the EU in the mid-2000s. Although China may have executed an industrial policy to expand domestic production in this sector, it had not completely shut its market to foreign firms. Instead, it had signed contracts with foreign incumbents, even as it worked to provide expanded opportunities for the upstart domestic firm. But if the Europeans were now going to try to shut Nuctech out of its market using antidumping duties, why not do the same in response?

What impact then did the antidumping duties imposed on both parties have on trade flows? As expected, imports from the affected party dropped dramatically following the imposition of antidumping duties. Chinese exports of $\mathrm{x}$-ray scanners to the EU in 2010 (i.e., the first full year following the imposition of provisional antidumping duties by the Commission) fell by $62 \%$ from their peak level in 2008 , the last full year prior to the antidumping investigation. Similarly, European exports of x-ray scanners to China in 2011 (i.e., the first full year following the imposition of provisional antidumping duties by MOFCOM) fell by $87 \%$ from their peak level in 2008. In short, the trade statistics suggest that the antidumping duties led to significantly lower imports.

If Nuctech and the Chinese government's aim was to punish Smiths and the EU for hitting Nuctech with antidumping duties, then the retaliatory tit-for-tat measures clearly worked. China demonstrated clearly that it could give as good as it could get. Trying to shut out a rising Chinese upstart, especially one supported by Chinese industrial policy, was not without consequences for the established incumbents.

There is, of course, another question: Were the tit-for-tat actions effective in bolstering the domestic firm's competitiveness in the aftermath of the antidumping measures imposed against it overseas? Did the Chinese government provide its upstart producer with a boost by closing off more of the domestic market as a response to the Smiths' decision to press the EU for antidumping duties? Again, the trade flow data suggests the possibility that the answer may be yes. Chinese exports in this product category fell in 2009 and 2010 subsequent to imposition of antidumping duties. However, Chinese exports to the EU have rebounded significantly, and in 2013, they reached $70 \%$ of their value prior to the antidumping duties.

These results suggest that if a government is seeking to counter the negative impact of an antidumping action imposed by a trading partner on its producer, a retaliatory tit-for-tat antidumping measure in the same market can 'work'. Retaliation is effective in the sense that it can alter patterns of trade positively, at 
least in the near term, for the domestic firm. However, it is important to note two caveats: First, the likelihood of success associated with such a strategy may depend, among other things, on the size of the domestic market of the upstart. If it is significantly large, as in the case of China, then additional protection afforded by the titfor-tat measure can provide a boost to offset the harm suffered from the antidumping measure imposed overseas by the incumbent's government. Second, depending on the market, one need not turn necessarily to antidumping measures as a means of retaliation and assistance to the upstart domestic firm. Other policy instruments, such as government procurement, may also exist, especially for sectors heavily reliant on government contracts and for governments that are not signatories to the GPA. In that sense, this may again be further evidence that the process here was at least partially firm-driven rather than purely government-driven.

\subsection{Price comparisons in an injury investigation: lingering questions left unresolved by the Panel Report}

The China-X-Ray Equipment decision is also significant in its attempt to clarify open questions over how authorities in antidumping investigations are to perform price comparisons when assessing injury pursuant to Article 3 of the ADA. Below, we explain the significance of this issue and attempt to highlight its importance. We suggest that the Panel was correct to take steps to clarify the legal discipline, but we argue that it did not spell out enough. We end by highlighting several questions left unanswered by the Panel ruling.

The question of the scope of the product under investigation is a key element of any antidumping investigation. Investigators must resolve this question before they can assess whether dumping is occurring and whether it is causing injury to the domestic producer to require the imposition of antidumping duties. Their decision, in turn, will affect several elements of the investigation, including what data are collected from which set of firms, foreign and domestic.

The ADA provides inadequate guidance on how investigating authorities are to define 'like' products. ADA Article 2.6 simply states that the 'like product shall be interpreted to mean a product that is identical, i.e., alike in all respects to the product under consideration ...' WTO Panels have afforded investigating authorities broad discretion, but as the Panel ruling in China-X-Ray Equipment makes clear, there are limits to this discretion.

During the investigation, Smiths and MOFCOM vehemently disagreed over the proper product scope for the investigation. Smiths claimed that low-energy and high-energy scanners are distinct goods on account of differences in their physical characteristics, end-uses, technological features, mechanical features, manufacturing processes, and prices. ${ }^{113}$ Furthermore, Smiths asserted that the two do not compete against each other. As Smiths exported only low-energy scanners during 
the period of investigation, Smiths argued that high-energy scanners should be excluded from the product scope under investigation. ${ }^{114} \mathrm{MOFCOM}$, on the other hand, disagreed, and considered both high- and low-energy scanners as part of its investigation, which contributed to its finding of injury to Nuctech on account of price undercutting and suppression from Smiths' imports.

The energy level of scanners is measured in kiloelectronvolts $(\mathrm{keV})$. Low-energy scanners, for example, are the ones used to scan luggage at an airport or bags at a subway station. High-energy scanners, on the other hand, are the ones used to scan railcars and trucks. The prices between low- and high-energy scanners differ greatly because of complexity and size. The EU maintained that these are two distinct categories; a consumer for one would never consider the other when making its purchases. China, on the other hand, argued that 'there is "no hard and clear dividing line" between high- and low-energy scanners, but rather a "single continuum" of scanners. ${ }^{115}$

Note that this issue is by no means specific to $\mathrm{x}$-ray scanners. Consider, for example, flat-screen monitors. Are there two distinct categories - small flat-screen monitors, for example, used with home computers, and large flat-screen monitors used to project information at airports? Or is there a single continuum of flat-screen monitors? In each of these instances, there are clear distinctions between the categories, including in terms of price and consumer end-use. But are the differences so distinct that they should not be considered 'like' products? If so, how does one draw the line between categories? For x-ray scanners, is it at $250 \mathrm{KeV}, 300$ $\mathrm{KeV}$, or some other level? Similarly, for flat-screen monitors, do we divide the two categories at 16 inches, 30 inches, or some other level?

The question is to what extent decisions made on such questions by administrative agencies in domestic litigation should be subject to review by the WTO. In the past, the WTO has shown itself to be very reluctant to challenge the line-drawing determinations of domestic authorities. For example, in another recent case, EUFootwear, the tables were turned, with China challenging the EU's determination in an antidumping case on Chinese footwear. The Commission had decided to lump adult dress shoes, children's leather sandals, and low-end athletic shoes into the scope of the product investigation, but not high-end athletic shoes. The dividing line, according to the Commission, was $€ 7.50$ per pair; special-technology athletic shoes above this price were excluded from the investigation whereas those below it were included. ${ }^{116}$ China challenged the EU's line-drawing when determining the scope of products under investigation, but lost. The Panel reaffirmed earlier decisions suggesting that it did not have the authority to review the domestic

114 Ibid.

115 Ibid., para. 7.17.

116 Panel Report, EU-Footwear, paras. 7.311-7.312. 
administrative agency's determination of the product scope under investigation through ADA Article 2.6.117

Note that from an economist's point-of-view, substitutability in consumption is a key factor in determining product grouping. Economic analysis would suggest that adult formal shoes and children's sandals are very distinct products and should not be grouped together. On the other hand, it is unclear that this is the case with high-end athletic shoes. An adult male would never consider children's footwear for a stroll around town but might choose athletic shoes. If the dividing line is drawn at $€ 7.50$ per pair for athletic shoes, then the burden would appear to fall on the authority drawing this line to show that a consumer would only substitute shoes below this line but not above it. Yet, that was not the approach embraced by the WTO in EU-Footwear. Instead, the earlier Panel left investigating authorities with wide discretion in determining 'like' products and in deciding where to draw the line in deciding to exclude a subcategory of the 'like' product.

While the China-X-Ray Equipment case also involves line drawing, we draw attention to the fact that it has the opposite fact pattern. In EU-Footwear, the litigant (China) asserted that the defendant (the EU) had improperly drawn a line to subdivide a product category, thereby causing the product scope under investigation to be too narrow and discriminating against its producers' interest. In contrast, in the case at hand, the litigant (the EU) asserted that the defendant (China) had improperly failed to draw a line to subdivide a product category, thereby causing the scope to be too wide and discriminating against its producers' interest.

Possibly on account of the lessons learned from China's failed litigation claims in EU-Footwear, the EU decided not to challenge China on MOFCOM's determination that low- and high-energy x-ray scanners are 'like' product. ${ }^{118}$ EU litigators did not argue, as Smiths had, that the two categories are distinct and MOFCOM was wrong to lump the two together. They avoided making any allegation that China violated ADA Article 2.6. Instead, the EU mounted a more indirect attack.

The EU noted that 'there is a wide and recognisable gap between high- and lowenergy scanners', leading to 'very large disparities in price' ${ }^{119}$ However, it did not then proceed to argue that this gap should have been the basis for excluding highenergy scanners from the investigation altogether. Instead, the EU simply asserted that MOFCOM should have taken these price disparities into account when

117 See ibid., para. 7.312, citing Panel Reports in US-Softwood Lumber V, Korea-Certain Paper, and EC-Salmon (Norway).

118 The Panel Report notes that although MOFCOM rejected Smiths' argument that high-energy scanners should be excluded from the product under investigation, the EU 'does not pursue this product scope argument in these proceedings'. Panel Report, China-X-Ray Equipment, para. 7.16.

119 Ibid., para. 7.17. 
conducting its price undercutting and price suppression analyses and that its failure to do so violated Article 3.2 of the ADA. ${ }^{120}$

When it comes to the question of how investigating authorities are to compare prices during an injury analysis, the ADA is relatively silent. This stands in sharp contrast to the related question of how price comparisons are to be done as part of the calculation of the dumping margin. The second sentence of Article 3.2, which covers the injury analysis, simply states that authorities are to consider price undercutting and price suppression, without any mention of how this is to be done. ${ }^{121}$ On the other hand, ADA Article 2.4.2, which pertains to the calculation of the dumping margin, sets forth in excruciating detail the permissible methodology for price comparisons. ${ }^{122}$ The law's meaning has been further clarified through a long line of jurisprudence surrounding questions of zeroing.

Past WTO Panels, however, have made clear that the law on price comparisons for dumping margin calculations cannot be simply transposed to Article 3 and the injury analysis. ${ }^{123}$ However, the law on price comparisons for the injury analysis has not been well established by subsequent jurisprudence. In China-GOES, the Appellate Body simply agreed that the Panel below was correct in declaring that 'an investigating authority must ensure comparability between prices that are being compared' as part of the injury analysis. ${ }^{124}$ How specifically this is to be done was a question left for a future case.

China-X-Ray Equipment, therefore, should be understood as an attempt by a later Panel to clarify further the Appellate Body's ruling in China-GOES on ADA Article 3. While it does so to an extent, we argue that the Panel Report still leaves questions unresolved. We explain in greater detail below.

120 Ibid., para. 7.13. Note that there was disagreement between the parties as to whether MOFCOM proceeded on the basis of price undercutting or price suppression. The Panel Report discusses an investigating authority's behavior under both circumstances, but proceeds on the basis that MOFCOM made a finding of price suppression. See ibid., para. 7.54.

121 Specifically, it reads: 'With regard to the effect of the dumped imports on prices, the investigating authorities shall consider whether there has been a significant price undercutting by the dumped imports as compared with the price of a like product of the importing Member, or whether the effect of such imports is otherwise to depress prices to a significant degree or prevent price increases, which otherwise would have occurred to a significant degree'.

122 It explains that calculations 'shall normally be on the basis of a comparison of a weighted average normal value with a weighted average of prices of all comparable export transactions or by a comparison of normal value and export prices on a transaction-to-transaction basis'. Furthermore, it adds that '[a] normal value established on a weighted average basis may be compared to prices of individual export transactions if the authorities find a pattern of export prices which differ significantly among different purchasers, regions or time periods, and if an explanation is provided as to why such differences cannot be taken into account appropriately by the use of a weighted average-to-weighted average or transaction-to-transaction comparison'. WTO Anti-Dumping Agreement, Article 2.4.2.

123 See Panel Report, European Communities - Anti-Dumping Duties on Malleable Cast Iron Tube or Pipe Fittings from Brazil, WT/DS219/R, adopted 18 August 2003, paras. 7.292-7.293; Panel Report, EC-Fasteners (China), para. 7.328.

124 Appellate Body Report, China-GOES, para. 200. 
After determining that high- and low-energy scanners are 'like' products, MOFCOM proceeded to compare the prices of the dumped imports and the like domestic product for the purposes of its price undercutting and price suppression analysis. For both the dumped foreign imports and the like domestic products, MOFCOM calculated the average unit value of the product by dividing total value by total quantity. ${ }^{125}$ China argued that since MOFCOM applied the same methodology of calculating a weighted average for the dumped imports and the like domestic products, it fulfilled the requirements of ADA Article 3.2 which simply requires that such a comparison be made. ${ }^{126}$

The EU contended that MOFCOM's technique was insufficient to meet the Appellate Body's command in China-GOES that an investigating authority must 'ensure comparability' across products when undertaking a price undercutting analysis. The EU argued that even when investigating authorities find goods to be 'like' product, they must nevertheless inquire into whether price differences exist across the goods that fall within the category of 'like' products. Where these differences are significant enough, then the authorities must make adjustments to ensure proper comparability. ${ }^{127}$ In other words, authorities could not simply take weighted averages of the two bundles - dumped imports and like domestic products - without taking into consideration the product composition of the bundles, as MOFCOM had done. To do so violated WTO law.

Note that when viewed from a strict textualist perspective, the validity of the EU's argument is questionable. Article 3.2 of the ADA simply states that 'the investigating authorities shall consider whether there has been a significant price undercutting by the dumped imports as compared with the price of a like product'. If A and $\mathrm{B}$ are 'like' products, then Article 3.2 suggests that investigating authorities are at liberty to compare the prices of A and B as they see fit. Nothing in the text itself suggests that under certain circumstances, the price of dumped imports of A cannot be compared with the price of domestically produced $\mathrm{B}$, but must instead be compared with domestically produced A. The textualist would further note that the bare language of Article 3.2 stands in stark contrast to that of Article 2.4.2, which places further constraints to ensure price comparability. The fact that this detail was consciously omitted from Article 3 lends further support to an argument that authorities enjoy wide discretion in how they choose to compare the prices of $\mathrm{A}$ and $\mathrm{B}$ once they find that the two are 'like' products.

For example, consider if $\mathrm{A}$ is a red apple and $\mathrm{B}$ is a green apple. Is it the case that the price of a dumped red apple must be compared with the price of a domestically produced red apple? Or can it also be compared against the price of a domestically produced green apple? In this example, the price differences between the two are

125 Panel Report, China-X-Ray Equipment, paras. 7.62-7.63.

126 Ibid., para. 7.24.

127 Ibid., para. 7.16 . 
not usually that significant. To an outsider, the question might seem to be trivial, although to a fruit farmer with thin profit margins, the issue of a few cents may well matter. Red and green apples are clearly 'like' products, and Article 3.2 seems to grant authorities discretion to compare the prices of dumped red apples against domestic green apples.

But what if the price differences are much larger? Suppose A is a white mushroom and B is a truffle, which is much rarer and more expensive. Or A is farmed salmon and B is wild salmon. One might argue that the two are not 'like' products because of different end-uses. But suppose, as was true here, both sides agreed that the authorities enjoyed the discretion to find them to be 'like' products. Do they, because of price differences, no longer enjoy the flexibility to compare A versus B?

The cleaner approach to handling such cases would simply be to opine further regarding the 'likeness' jurisprudence in Article 2.6 of the ADA. But because such challenges have failed, WTO members are increasingly turning to claims under Article 3 instead, as the EU did in this case. The Appellate Body's ruling in China-GOES had already opened the door for adjudicators to suggest that investigating authorities do not enjoy unfettered discretion when comparing prices between foreign and domestic goods. The Panel in China-X-Ray Equipment goes a bit further to fill in some of the details.

The Panel's holding in this case should be understood as suggesting that even when A and B are determined to be 'like' products, the investigating authorities must consider the statistical distribution of $\mathrm{A}$ and $\mathrm{B}$ within the bundle of dumped imports and like domestic products when making its price comparisons under Article 3. It cannot simply just compare the two bundles without due regard to their composition.

Inclusion of different versions of a product is not necessarily inappropriate in calculating averages so long as the underlying statistical distribution is similar. Unfortunately, this was not the case in this particular investigation. In particular, the EU firm sold none of the high-energy scanners in China during the period of investigation while Nuctech produced both high- and low-energy scanners. If the difference in price across the two is not significant, as is the case with red and green apples, then the differences in composition may not matter much to the eventual outcome. But when they are significant, as is the case with $\mathrm{x}$-ray scanners and even mushrooms, then failure to make adjustments will skew the outcome. Including the more expensive high-energy scanners in the determination of Chinese prices would result in oversampling of the high priced goods and increase the price-underselling margin.

To see why this is the case, consider the following simple example. Suppose that Smiths sells two low-energy scanners at $\$ 200$ but sells no high-energy scanners. Nuctech also sells a single low-energy scanner at \$200 plus a high-energy version at $\$ 1,000$. Under the MOFCOM procedures used in this case, the foreign average unit value is $\$ 200$ while the domestic average is $\$ 600$, indicating significant price underselling by Smiths. But this comparison is only appropriate if the two 
scanners are 'similar'. If the authorities consider low-end scanners as the correct comparison, there is no price underselling at all since both foreign and domestic sales are an average of $\$ 200$ per unit.

MOFCOM defended its approach by arguing that the procedure is fair given that the same procedure is used for both domestic and foreign prices. In particular, MOFCOM calculated unit values for the EU firms by dividing the total value of imports (from customs data) by the number of units sold. They used aggregate sales data from Nuctech and also divided the value of domestic sales by the number of units sold. This approach is particularly problematic when individual prices vary significantly across the data sample: simple averages can hide enormous variability within. Left unsaid by MOFCOM is that Nuctech's exports of the relatively high-energy scanners (i.e., greater than $250 \mathrm{KeV}$ ) were the ones targeted by the EU action. If MOFCOM (or Nuctech) were acting to retaliate against Smiths' use of antidumping to restrict large cargo scanning systems or to help it gain a foothold in this market, it would not exclude these items in the dumping investigation.

From an economics perspective, then, we therefore agree with the Panel's ruling that where the product composition in the bundle of dumped imports and like domestic products differ, adjustments need to be made by an investigating authority to ensure proper comparability. But what about the legal question of whether the vague language of Article 3.2, especially in contrast to Article 2.4.2, is a signal of the treaty drafters' intention to afford authorities with broad discretion to perform price comparisons as they see fit? Is the Panel's ruling too activist in the sense that it chose to create a requirement not found in the text of the law itself?

While we are mindful that WTO panelists ought to interpret treaty provisions in strict adherence to the Vienna Convention on the Law of Treaties, in this particular instance, we think that the Panel did not overstep its authority. Instead, the textual hook can be found in Article 3.1 of the ADA. That provision suggests that investigating authorities, when making an injury determination (which includes the price undercutting and price suppression analyses at issue in this case), must do so on the basis of an 'objective' examination. To not take into account the product composition when large price differences exist across the set of goods that fall within the 'like' products basket, in our opinion, falls outside the bounds of what, in our opinion, is considered to be objective. Thus, the Panel was right to place some boundaries on the scope of the discretion enjoyed by investigating authorities when undertaking a price comparison of dumped imports against domestic like products.

This then leads to a basic question lurking in this case: Was the approach taken by MOFCOM done simply as a matter of administrative convenience? Or was it part of a concerted strategy to increase the chances of finding injury to further a broader industrial policy strategy? Under the former interpretation, MOFCOM was acting innocently; relying on aggregate data and simple average unit values for domestic and foreign sales allowed for cheap and simple comparisons. 
Alternatively, MOFCOM could have chosen this methodology deliberately so as to increase the likelihood that injury would be found to a domestic industry.

The Panel Report hints at suspicion that this choice might have been taken with forethought. It notes that Nuctech had provided, on its own initiative, price data on a model-by-model basis, allowing MOFCOM to easily compare prices by model. ${ }^{128}$ All MOFCOM had to do was to ask Smiths to provide comparable model-by-model pricing data. But MOFCOM chose not to ask the respondent. To not follow up when the information has already been provided by one party suggests that MOFCOM may well have intentionally chosen to avoid making price comparisons of this form.

Therefore, the Panel declared that MOFCOM's failure to make adjustments, despite being aware of the significant differences in uses, physical characteristics, and prices of high- and low-energy scanners, to ensure proper comparability amounted to a violation of ADA Articles 3.1 and 3.2. ${ }^{129}$ If it is the case that MOFCOM's actions were taken with forethought, then this example demonstrates how government authorities will resort to manipulating technical aspects of an antidumping investigation to help push forward an industrial policy. As we suggested earlier, the resort to WTO litigation will then focus on highly technical issues - such as those related to product market definition and price comparison calculations under Article 3 -in an attempt to affect the impact of antidumping measures and strategic industrial policy.

Importantly, the Panel ruling leaves unresolved several important questions regarding price comparisons for an Article 3 injury analysis under the ADA. Future WTO Panels, and eventually the Appellate Body, should assist with providing greater clarity on three sets of questions.

First, the Panel simply finds MOFCOM's behavior to be problematic. It does not clarify what types of adjustments, had they been made, would have sufficed to satisfy the law. Would it have been fine for MOFCOM to simply exclude highenergy scanners? Could it have otherwise used the same exact calculation methodology if it had limited the aggregate data to only low-energy scanners? Or must it have undertaken price comparisons on a model-by-model basis? Did it need to undertake a transaction-by-transaction analysis? Because the Panel only states that adjustments are necessary but does not clarify what these must entail, investigating authorities are left to speculate until the question is clarified in another future case.

Second, the Panel notes that even if high- and low-energy scanners are 'like' products, adjustments were warranted in light of the differences in three factors: (1) product characteristics; (2) use; and (3) price. Must there be differences along all three dimensions before an adjustment is necessary, or would differences across

128 Ibid., para. 7.36 .

129 Ibid., paras. 7.81-7.92, and 7.97. 
a subset of these factors have also sufficed? More specifically, is it critical that the uses of A and B be different? The Panel's decision to emphasize this difference suggests that it may be. But suppose A are luxury watches and B are non-luxury watches. Their use is nearly identical, although their physical characteristics and prices differ. Under this scenario, if the product mixes across dumped imports and domestic 'like' products differ, are adjustments also necessary? One might think that the answer is also yes. But the Panel ruling leaves unclear what factors must be considered and how any multifactor test is to work before the requirement to make adjustments to ensure comparability is triggered. Greater guidance for investigating authorities in terms of knowing when they must divide a basket of 'like' products and how fine the divisions must be would be helpful.

Third, the Panel ruling leaves unclear what burdens fall on the investigating authority in terms of seeking information to make adjustments. The Panel faults MOFCOM for not seeking model-by-model data from Smiths when this information was provided by Nuctech. The ruling therefore clarifies that where one party has submitted detailed information which allows for adjustments to be made, the investigating authority has a burden to seek comparable information from the other party. But what if this is not the case? Suppose, for example, that neither party had submitted data on a model-by-model basis. After all, it is not altogether clear that Nuctech should have done so proactively, as it did not serve its interests. Would MOFCOM, lacking sufficient data from both parties, then have been free to undertake the calculations as it did? Or would it nevertheless have been required to ask for data to make adjustments because it could already tell, based on HS-8 customs data, that the product mix of Smiths' imported products might be different than that of Nuctech? Again, greater clarity would be helpful.

To summarize, the China-X-Ray Equipment dispute helps to clarify some portion of the law with respect to product comparisons and price comparability in the injury analysis of an antidumping investigation. The focus on this element of the law is not altogether surprising. Manipulations of such calculations, as we have suggested, may serve as a means to bolster support for an industrial policy through antidumping. Furthermore, given the lack of success with challenges of the 'like' product definition under ADA Article 2.6, WTO members are choosing to make narrower claims, as the EU did in this case. If we are correct in our assessment, then we should expect more disputes with ADA Article 3 claims to surface in the coming years. The Panel's ruling in China-X-Ray Equipment certainly does not offer a definitive last word on this issue. In spite of the Panel's efforts, much of the law on this issue remains in need of further judicial clarification.

\section{Conclusion}

We have argued that the conventional account of the relationship between antidumping measures and strategic industrial policy is incomplete. We have sought 
to demonstrate that the relationship between the two does not always arise out of a government-driven, top-down policy. Instead, it may develop as a result of firmdriven actions taken in response to an industrial policy and a desire to enact tit-fortat trade remedies. The case study of tit-for-tat anti-dumping measures levied by the EU and China in the Smiths-Nuctech rivalry offers an excellent example consistent with our argument. It highlights how the relationship between the two policy instruments is much more complicated than that posited in the conventional account.

Understanding the more complex nature of this relationship is important because, as we have sought to demonstrate in our case study analysis, this strategy can work. When antidumping measures are understood not as a means to protect an infant industry but instead as a tool to counteract trade remedies taken in response to one's industrial policy, we see that they can be an effective tool. We posit that this efficacy may require certain conditions to hold true. We leave it to future research to clarify how common this dynamic might be. Still, if we are correct, then we can expect the number of instances where antidumping measures are entwined with an industrial policy to grow in coming years as industrial policy makes a comeback.

Understanding this relationship is also important because if this phenomenon persists, then it is likely to feature increasingly in future WTO disputes. Because the claims in the litigation itself are highly technical, the linkages between an antidumping measure and industrial policy may not always be obvious upon first glance. It is only when the nature of the relationship is understood that the imprimatur of industrial policy in a WTO antidumping case becomes clear. WTO litigation, however, can be an important element of the multifaceted strategic contest between rival firms to gain greater share of global markets - and the efforts of governments to support their domestic firms. The stakes are high; the outcome of a WTO case can offer one side an advantage (or undo an advantage). Moreover, because elements of the law remain unclear, there is ample room for further legal contestation. Therefore, the China-X-Ray Equipment dispute is but a foreshadowing. There is likely more to come.

WTO Panels and the Appellate Body have offered wide discretion, to date, on how authorities can define the 'like' product in antidumping investigations as well as how they engage in price comparisons of the dumped product with the domestic 'like' product to calculate dumping margins and examine the existence of injury. The Panel in China-X-Ray Equipment dispute has provided at least some guidance about the limits of agency discretion in determining the boundary of the relevant product for price comparisons in antidumping cases. But substantial questions persist. As the ongoing China-HP-SST disputes demonstrate, the issue will be a recurring theme in future WTO disputes. ${ }^{130}$ How future Panels, and eventually the Appellate Body, will choose to clarify this boundary remains to be seen.

130 Two separate cases, filed by Japan (DS454) and the EU (DS460), are ongoing as of this writing. Both involve claims that China violated Articles 3.1 and 3.2 of the ADA. See Request for Consultations 


\section{References}

Ahrens, N. (2010), Innovation and the Visible Hand: China, Indigenous Innovation, and the Role of Government Procurement, Washington, DC: Carnegie Endowment for International Peace.

Aldrick, P. et al. (2009), 'European Union Probes Chinese "Soft Loans" Ploy Over NucTech', The Telegraph, 19 July 2009.

Bora, B., P. J. Lloyd, and M. Pangetsu (2000), 'Industrial Policy and the WTO', UNCTAD Policy Issues in International Trade and Commodities Study Series No. 6.

Bown, C.P. (ed.) (2011), The Great Recession and Import Protection: The Role of Temporary Trade Barriers, Washington, DC: World Bank.

(2014), 'Global Antidumping Database', The World Bank, http://econ.worldbank.org/ttbd/gad/.

Bown, C. P. and M. Crowley (2007), 'Trade Deflection and Trade Depression', Journal of International Economics, 72(1): 176-201.

Chandra, P. (2011), 'A Sleeping Giant of Temporary Trade Barriers', in C. Bown (ed.), The Great Recession and Import Protection: The Role of Temporary Trade Barriers, Washington, DC: World Bank.

Charnovitz, S. and B. Hoekman (2013), 'US-Tyres: Upholding a WTO Accession Contract-Imposing Pain for Little Gain', World Trade Review, 12(2): 273-296.

Dick, A. (1994), 'Does Import Protection Act as Export Promotion: Evidence from the United States', Oxford Economic Papers, 46: 83-101.

Eaton, J. and G. Grossman (1986), 'Optimal Trade and Industrial Policy Under Oligopoly', Quarterly Journal of Economics, 101(2): 383-406.

Erickson, A. S. (2010), 'The Container Security Initiative and US-China Relations', in A. Erickson et al. (eds.), China, the United States, and 21st Century Sea Power: Defining a Maritime Partnership, Annapolis: Naval Institute Press.

Faircloth, G. et al. (2009), 'Probe Involves Firm Linked to China Leader's Son', Wall Street Journal, 22 July 2009.

Feris, L. (2011), 'Subsidies as an Instrument of Industrial Policy: Are They WTO Compliant?', SAIIA Policy Briefing No. 31.

Finger, J. M. and J. J. Nogues (eds.) (2005), Safeguards and Antidumping in Latin American Trade Liberalization: Fighting Fire with Fire, Washington, DC: World Bank.

$\mathrm{Fu}, \mathrm{X}$. and Y. Gong (2011), 'Indigenous and Foreign Innovation Efforts and Drivers of Technological Upgrading', World Development, 39(7): 1213-1225.

Goldstein, A. (2002), 'Embraer: From National Champion to Global Player', CEPAL Review 77: 97-115.

Goodwin, J. (2008), 'Port of L.A. Buys Huge Chinese X-ray System', Global Security News, 6(10): 1 \& 14.

Greenway, D. and C. Milner (1993), Trade and Industrial Policy in Developing Countries: A Manual of Policy Analysis, Ann Arbor: University of Michigan Press.

Hindley, B. and P. Messerlin (1996), Antidumping Industrial Policy: Legalized Protectionism in the WTO and What to Do About It, Washington, DC: American Enterprise Institute Press.

Hufbauer, G. C., J. J. Schott, and C. Cimino (2013), Local Content Requirements: A Global Problem, Washington, DC: Peterson Institute for International Economics.

Irwin, D. (2000), 'Did Late-Nineteenth-Century US Tariffs Promote Infant Industries? Evidence from the Tinplate Industry', The Journal of Economic History, 60(2): 335-360.

Konings, J., H. Vandenbussche, and L. Springael (2001), 'Import Diversion Under European Antidumping Policy’, Center for Economic Policy Research Discussion Paper Series No. 2785.

by Japan, China - Measures Imposing Anti-Dumping Duties on High-Performance Stainless Steel Seamless Tubes ('HP-SSST') from Japan, WT/DS454/1, 7 January 2013; Request for Consultations by the European Union, China-Measures Imposing Anti-Dumping Duties on High-Performance Stainless Steel Seamless Tubes ('HP-SSST') from the European Union, WT/DS460/1, 18 June 2013. 
Krugman, P. (1984), 'Import Protection as Export Promotion: International Competition in the Presence of Oligopoly and Economies of Scale', in H. Kierzkowski (ed.), Monopolistic Competition and International Trade, Oxford: Oxford University Press.

Lin, J. Y. and C. Monga (2010), 'Growth Identification and Facilitation: The Role of the State in the Dynamics of Structural Change', World Bank Policy Research Working Series.

Luzio, E. and S. Greenstein (1995), 'Measuring the Performance of a Protected Infant Industry: The Case of Brazilian Microcomputers', Review of Economics and Statistics, 77(4): 622-633.

Malhotra, N. and S. Malhotra (2005), 'Liberalization and Protection: Antidumping Duties in the Indian Pharmaceutical Industry', Journal of Economic Policy Reform, 11(2): 115-122.

Moore, M. O. and M. Zanardi (2011), 'Trade Liberalization and Antidumping: Is There a Substitution Effect?', Review of Development Economics, 15(4): 601-619.

Neven, D. and P. Seabright (1995), 'European Industrial Policy: The Airbus Case', Economic Policy, 21: 313-358.

Owen, G. (2012), 'Industrial Policy in Europe Since the Second World War: What Has Been Learnt?', ECIPE Occasional Paper No. 1/2012.

Pangetsu, M. (2000), 'Industrial Policy and Developing Countries', in B. M. Hoekman et al. (eds.), Development, Trade, and the WTO: A Handbook, Volume 1, Washington, DC: World Bank.

Prusa, T. (1997), 'The Trade Effects of US Antidumping Actions', in Robert Feenstra (ed.), The Effects of US Trade Protection and Promotion Policies, Chicago: University of Chicago Press.

Prusa, T. and S. Skeath (2002), 'The Economic and Strategic Motives for Antidumping Filings', Review of World Economics (Weltwirtschaftliches Archiv), 138(3): 389-413.

Prusa, T. and E. Vermulst (2013), 'United States - Definitive Anti-Dumping and Countervailing Duties on Certain Products from China: Passing the Buck on Pass-Through', World Trade Review, 12(2): 197-234.

Rodrik, D. (1995), 'Getting Interventions Right: How South Korea and Taiwan Grew Rich', Economic Policy, 20: 53-107.

— (2010), 'The Return of Industrial Policy', Project Syndicate, http://www.project-syndicate.org/co mmentary/the-return-of-industrial-policy.

Segal, A. (2010), 'China's Innovation Wall: Beijing's Push for Homegrown Technology', Foreign Affairs, 28 September 2010.

Stiglitz, J. E. and J. Y. Lin (eds.) (2013), The Industrial Policy Revolution I: The Role of Government Beyond Ideology, London: Palgrave Macmillan.

Stiglitz, J. E., J. Y. Lin, and E. Patel (eds.) (2013), The Industrial Policy Revolution II: Africa in the TwentyFirst Century, London: Palgrave Macmillan.

Westphal, L. E. (1990), 'Industrial Policy in an Export Propelled Economy: Lessons From South Korea's Experience', Journal of Economic Perspectives, 4(3): 41-59.

Wu, M. (2012), 'Antidumping in Asia's Emerging Giants', Harvard International Law Journal, 53(1): $101-184$.

Zeng, K. (2012), 'Trade Deflection, Retaliation, and Developing-Country Antidumping Initiation Against China', World Economy, 45(2): 38-64.

Zheng, Y. and R. Abrami (2011), 'The New Face of Chinese Industrial Policy: Making Sense of Anti-Dumping Cases in the Petrochemical and Steel Industry', Journal of East Asian Studies, 11: 373-406. 